\title{
Thermal Treatment of Biomass: A Bibliometric Analysis- The Torrefaction Case
}

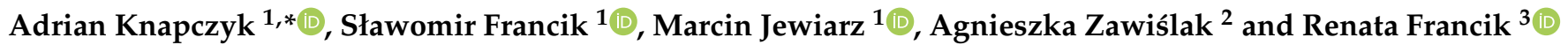 \\ 1 Department of Mechanical Engineering and Agrophysics, University of Agriculture in Krakow, Balicka 120, \\ 31-120 Kraków, Poland; slawomir.francik@urk.edu.pl (S.F.); marcin.jewiarz@urk.edu.pl (M.J.) \\ 2 Department of Biotechnology and General Food Technology, Faculty of Food Technology, University of \\ Agriculture in Krakow, 30-149 Kraków, Poland; agnieszka.zawislak@urk.edu.pl \\ 3 Institute of Health, State Higher Vocational School, Staszica 1, 33-300 Nowy Sacz, Poland; \\ rfrancik@pwsz-ns.edu.pl \\ * Correspondence: adrian.knapczyk@urk.edu.pl
}

Citation: Knapczyk, A.; Francik, S.; Jewiarz, M.; Zawiślak, A.; Francik, R. Thermal Treatment of Biomass: A Bibliometric Analysis-The Torrefaction Case. Energies 2021, 14 162. https://doi.org/10.3390/ en14010162

Received: 25 November 2020 Accepted: 24 December 2020 Published: 30 December 2020

Publisher's Note: MDPI stays neutral with regard to jurisdictional clai$\mathrm{ms}$ in published maps and institutional affiliations.

Copyright: $(\odot 2020$ by the authors. Licensee MDPI, Basel, Switzerland. This article is an open access article distributed under the terms and conditions of the Creative Commons Attribution (CC BY) license (https:// creativecommons.org/licenses/by/ $4.0 /)$.

\begin{abstract}
The aim of the paper was to summarize and discuss current research trends in biomass thermal treatment (torrefaction process). Quantitative analyses were carried out, in which the main countries, research units and scientists were indicated. The analysis showed a clear upward trend in number of publications after 2010. Most scientists on selected topics come from China, USA, Canada, South Korea, Republic of China, Poland (Web od Science-Core Collection (WoS-CC) and Scopus databases). Quantitative analysis also showed that the most relevant WoS-CC categories in the summary are: Energy Fuels, Engineering Chemical, Agricultural Engineering, Biotechnology Applied Microbiology and Thermodynamics and Scopus Subject area: Energy, Chemical Engineering, Environmental Science, Engineering and Chemistry. Thematic analysis included research topics, process parameters and raw materials used. Thematic groups were separated: torrefaction process (temp.: $150-400^{\circ} \mathrm{C}$ ), hydrothermal carbonization process (HTC) (temp: $120-500{ }^{\circ} \mathrm{C}$ ), pyrolysis process (temp.: $200-650{ }^{\circ} \mathrm{C}$ ) and gasification and co-combustion process (temp.: $350-1600^{\circ} \mathrm{C}$ ). In the years 2015-2019, current research topics were: new torrefaction technologies (e.g., HTC), improvement of the physico-mechanical, chemical and energetic properties of produced fuel as well as the use of torrefied biomass in the process of pyrolysis, gasification and co-combustion. The raw materials used in all types of biomass thermal treatment were: energy crops, wood from fast-growing and exotic trees, waste from the agri-food industry, sewage sludge and microalgae.
\end{abstract}

Keywords: torrefaction; hydrothermal carbonization; pyrolysis; gasification; bibliometric analysis; research trends; research topic; scientometric; solid biomass

\section{Introduction}

In recent years, there has been an increase in population around the world. This clearly affects the increase in energy consumption [1,2]. Most energy comes from the burning of fossil fuels, which is associated with the emission of large amounts of greenhouse gases [3]. Therefore, a reduction in the usage of fossil fuels is needed. There should be an increase in participation of renewable energy sources (RES) in general energy balance [4].

In the European Union (EU) policy climate issues play an important role. An element of EU's energy policy is "2020 climate \& energy package" so-called "three 20 targets" (20\% improvement in energy efficiency reduction greenhouse gas emissions, $20 \%$ of EU energy from RES, 20\% improvement in energy efficiency), voted through by the European Parliament in 2008. It is a collection of acts aiming to ensure the achievement of EU objectives regarding counteracting the climate change. One of the objectives is increasing the share of RES up to $20 \%$ to 2020 [5,6].

The need to reduce the consumption of fossil fuels, greenhouse gas emissions and increase the expenditure on renewable energy has increased the interest of researchers in 
the subject of RES. Increasing demands regarding the protection of natural environment and the increasing demand for energy caused greater interest in RES which use biomass, sun, wind, water, sea and geothermal energy. This caused an intensive development of scientific research towards RES [7]. In Poland such research mainly regards RES using biomass, solar energy and wind energy. There are also researches regarding the energetic use of waste.

Numerous studies have showed that biomass has the greatest energy potential from all RES sources. Technologies for the processing and energy use of biomass can be applied in developing and developed countries [8,9]. In EU an directive has been taken in regarding biofuels (2015/1513) which promotes the use of renewable biofuels in EU Member States [4] There is an increase in researchers' interest in issues related to the production of biofuels from biomass, e.g., from energy crops, agricultural waste, etc. [10,11]. In Poland in 2014 $76 \%$ of energy from RES originated from solid biomass [6]. Biomass can be a raw material for the production of liquid biofuel, gaseous biofuel and solid biofuels [11,12] (Figure 1).

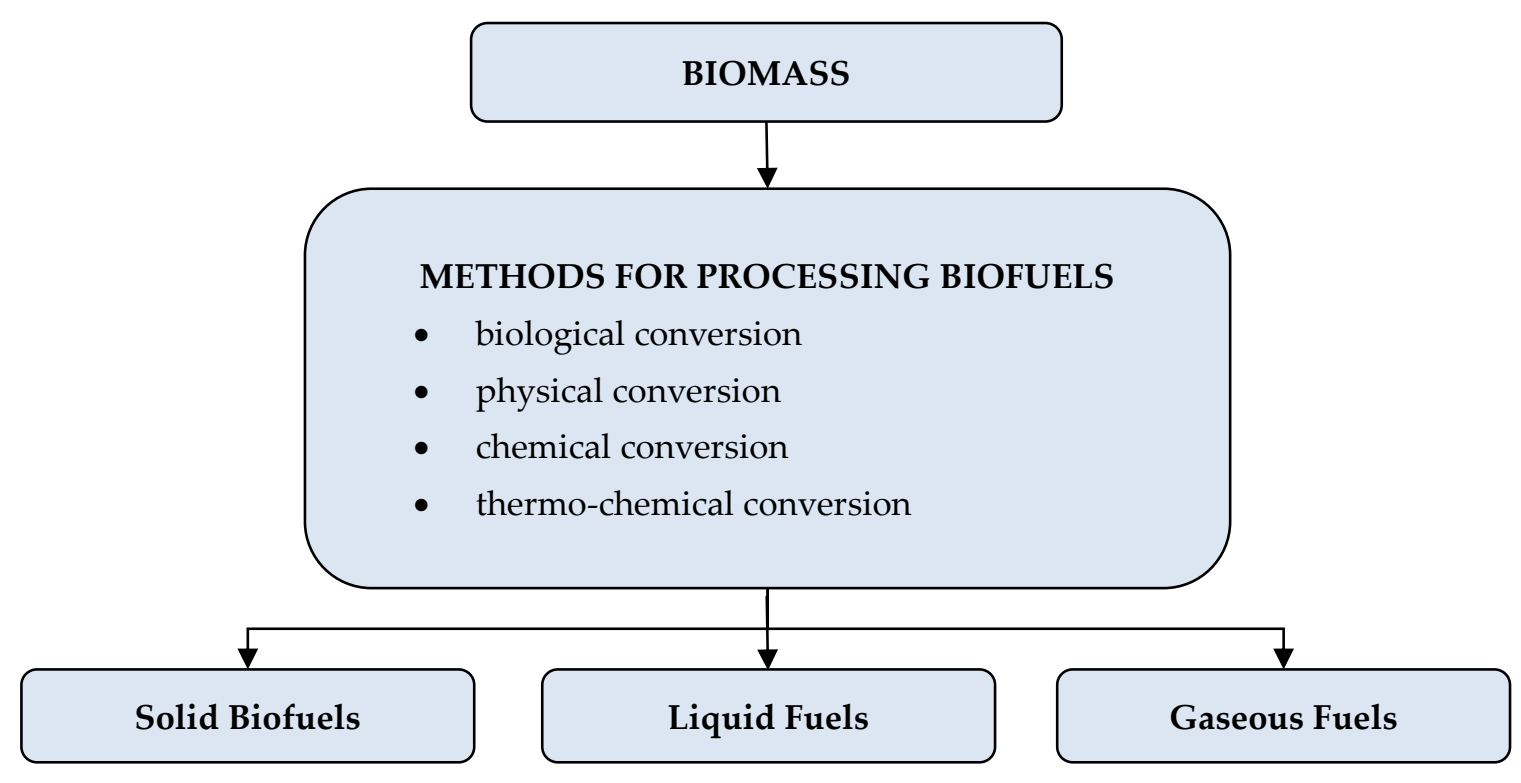

Figure 1. Classification of biofuels.

In order to meet the demand of the global energy market, research is ongoing on the search for new sources of biomass. These include: wood from eucalyptus and bamboo, energy crops, agricultural waste, agricultural and food industry waste, municipal waste, sewage sludge, etc. [6,8]. The use of lignocellulosic biomass of energy crops, e.g., miscanthus, willow, poplar, acacia or paulownia as a source is particularly interesting $[7,11,13]$.

According to current trends in research on solid biofuels presented by Knapczyk et al. [12] main groups of topics are: (1) searching for new raw materials for the production of solid biofuels-e.g., waste biomass from palm oil [14], sunflower husks [15], peanut shells [16], new species etc. [17,18], (2) optimization of the supply chain, warehouse logistics and biofuels legislation, e.g., development of and identification system to ensure the quality of biomass [19], legal analysis of the international standard classification of solid biofuels etc. [20] (3) optimization of plant cultivation, study of physicochemical properties of raw materials-e.g., determining the calorific value, chemical composition of elements and main energetic parameters in wood and bark of fast growing trees [21-26] and herbaceous etc. [27], (4) agglomeration process-e.g., assessment of physic-mechanical properties of agglomerate and the effect of added biochar and bio-oil etc. [10,28-32], (5) the torrefaction process-biomass torrefaction [33-38], hydrothermal waste carbonization, wood mixtures etc. $[39,40]$ and the remaining group, in which the authors raised topics such as composition testing and combustion modeling in household. 
Methods for processing biofuels can be divided into: biological conversion, physical conversion, chemical conversion and thermo-chemical conversion. These methods are used to improve the physico-mechanical and chemical parameters of biofuels. The resulting products have various applications, such as biofuels, agglomeration, fertilization, soil remediation and many more [41-44]. As a result of processing, the products can be used directly or serve as a raw material for further processing.

One of the main methods for processing solid biofuels is thermal processing. Depending on the temperature used the thermal processes can be divided into drying, torrefaction, pyrolysis and gasification (Figure 2). Each of these processes has different products and intermediates. With increasing temperature, energy parameters may increase, but this is associated with increased energy expenditure. Thermal biomass treatment can improve energy, physico-mechanical and chemical properties. The parameters of individual processes may vary depending on the temperature, atmosphere and exposure time. The efficiency of the process is also influenced by the raw material parameters (humidity, degree of comminution, etc.) $[45,46]$.
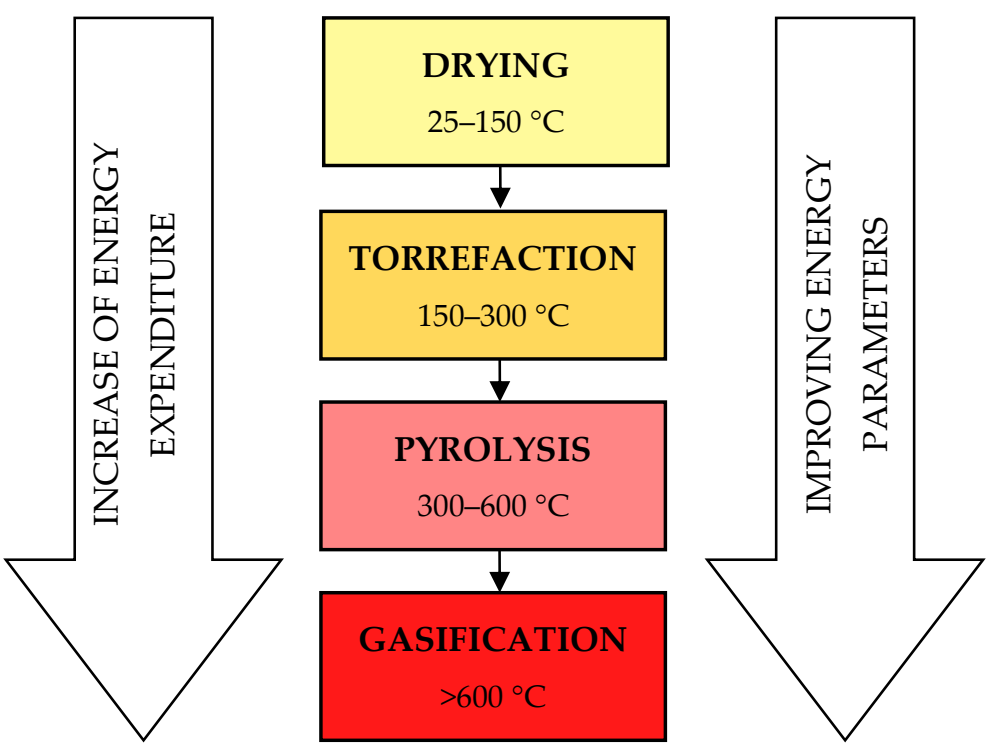

Figure 2. Biomass thermal treatment-processes and range of temperatures.

The thermal process with absence of air, is called pyrolysis. In the literature often the name is related to the process temperature. Low temperature range $\left(150-300{ }^{\circ} \mathrm{C}\right)$ is characteristic of the torrefaction and above 300 we have the right pyrolysis. This processes are both endothermic one, so energy needed to be supplied for the process [47-49].

Bibliometrics is a collection of mathematical and statistical tools used for objective assessment of scientific achievements. This term was used for the first time in 1969 by A. Pritchard [50]. Bibliometric analysis allows to highlight current research topics [12,51-55], observing scientific trends in the world and in the selected country [56,57]. It gives the opportunity to evaluate scientific units, journals, researchers based on selected parameters [58]. Using bibliometric techniques, it is also possible to indicate a network of connections between authors, countries, research topics. Data for bibliometric analysis should come from reputable and widely recognized databases of scientific publications and patents, such as Web of Science, Scopus. The main quantitative indicators include: the number of publications, number of citations, Impact Factor and Hirsch index.

The aim of the research was to determine the main research topics in the area of the use of thermal processing (torrefaction process) of biological materials and to indicate process parameters and raw materials. 


\section{Materials and Methods}

The research was carried out using the authors' methodology $[12,55,59,60]$ using bibliometric techniques (Figure 3).

The analyzes were divided into two stages:

I-quantitative analysis,

II-qualitative-thematic analyses.

The first stage involved searching for indexed documents in the Web of Science-Core Collection (WoS-CC) and Scopus database. The search period covered the years 1945-2019 in English. TOPIC documents were searched: "torrefaction *", type: article.

\section{Search in the WoS-CC and Scopus database}

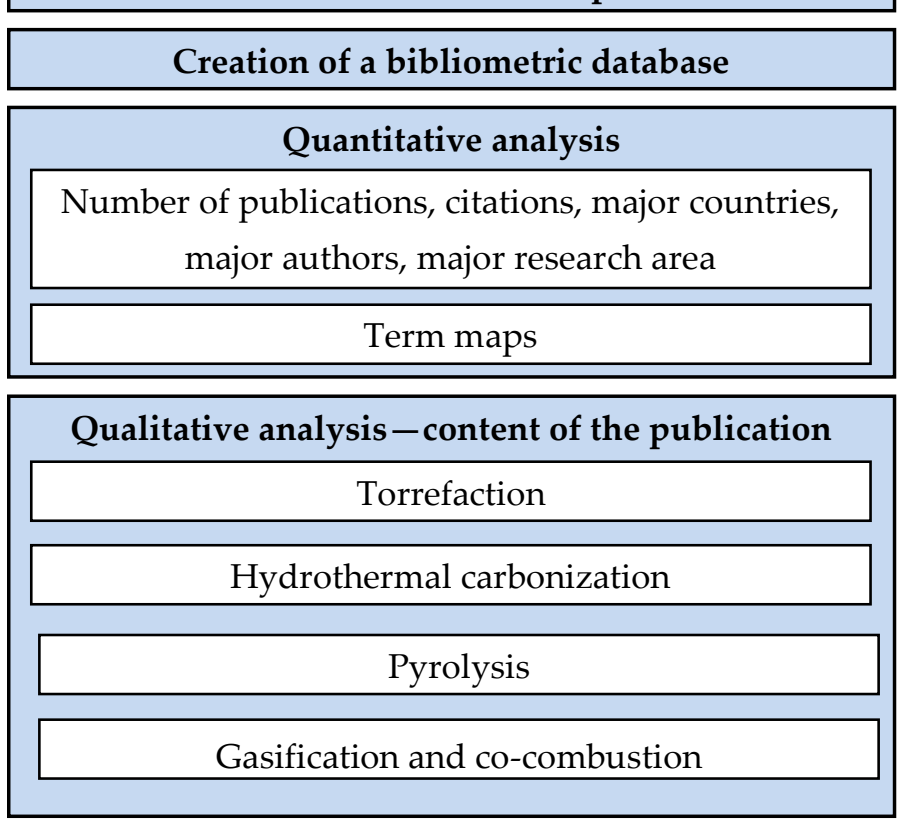

Figure 3. Diagram of research methodology.

Then bibliometric data (authors, title, year of issue, key words, additional key words, publishing house) was downloaded and quantitative analyses were performed. As part of them, the number of publications in years, number of publications in countries, leading scientists and main research centers dealing with biomass thermal treatment were shown. WoS-CC categories and Scopus Subject area were also indicated, which thematically concerned the publications.

The next stage was the analysis of keywords of the authors of the publication which were analyzed in the VOSviewer program. This program is free and is used to visualize bibliometric networks. The analyses may concern authors, keywords, journals, and others. Generated thematic maps can be created on the basis of the frequency of occurrence of keywords in years, citations, networks and others. All documents analyzed concerned the WoS-CC Energy Fuels category and Scopus Energy. Maps of terms were generated, which were used to analyze the frequency of occurrence of keywords in years and most often cited. Such maps allow to indicate current research topics and trends changes in years.

The last stage consisted of a detailed thematic analysis of the publication in the Open Access license for the entire Wos-CC: Energy Fuels category and Scopus Subject area: Energy. Open Access documents are widely available. This is especially important for industry. It makes it possible to use research results and implement selected technologies processes and process parameters in production Titles, keywords, abstracts as well as full publication texts were analyzed. The goal was to indicate process parameters, materials used for torrefaction and applications of this process. The analyzed publications were 
divided into three categories according to the technology used: (1) Torrefaction, (2) Hydrothermal carbonization (HTC), (3) Pyrolysis, (4) Gasification and co- combustion. The other group contains publications that focused on related topics. In each of the groups it is specified: application, process parameters and raw materials used in the biomass thermal treatment process.

\section{Results}

\subsection{Quantitative Analysis Results}

The search resulted in 1564 scientific articles published in journals in WoS-CC database and 1231 documents in Scopus. Among the found publications, 318 (WoS-CC) and 188 (Scopus) were published under the Open Access license. The oldest publication on torrefaction dates from 1919 and is entitled: Article on the theory of drying and torrefaction [61].

The most cited publications in WoS-CC and Scopus databases include:

- Bridgeman T.G. et al.-Total Citations: 474 WoS-CC/545 Scopus [62],

- Phanphanich M. and Mani S.-Total Citations: 432 WoS-CC/512 Scopus [63],

- Arias B. et al.-Total Citations: 427 WoS-CC/504 Scopus [64].

Figure 4 shows the distribution of the number of all publications indexed in WoS-CC and Scopus database. The years 2005-2019 were chosen to increase readability. A clear upward trend has been visible since 2010.

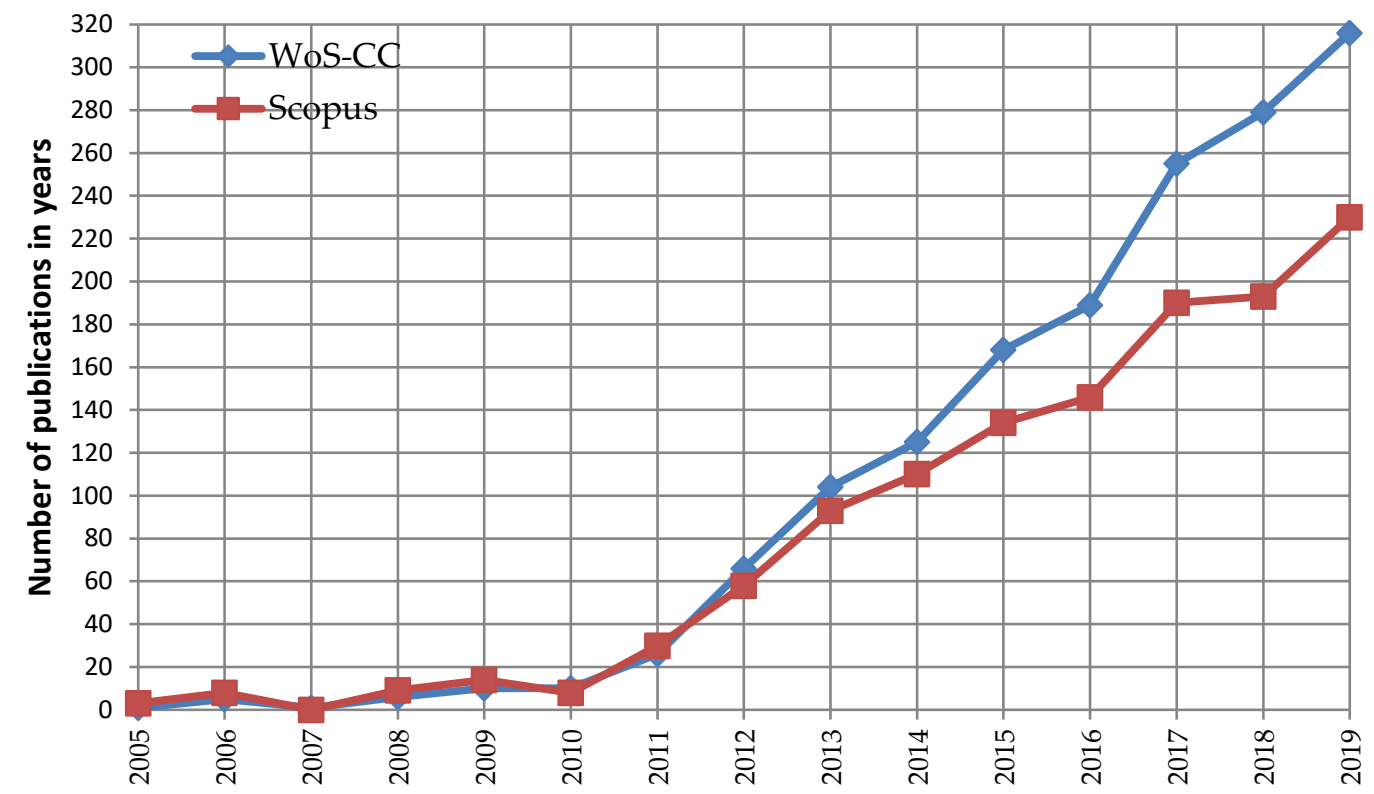

Figure 4. Number of articles in years indexed in WoS-CC and Scopus-2005-2019.

Figure 5 shows the distribution of the number of publications with Open Access license indexed in WoS-CC and Scopus database. The years 2005-2019 were chosen to increase readability. A clear upward trend has been visible since 2010. 


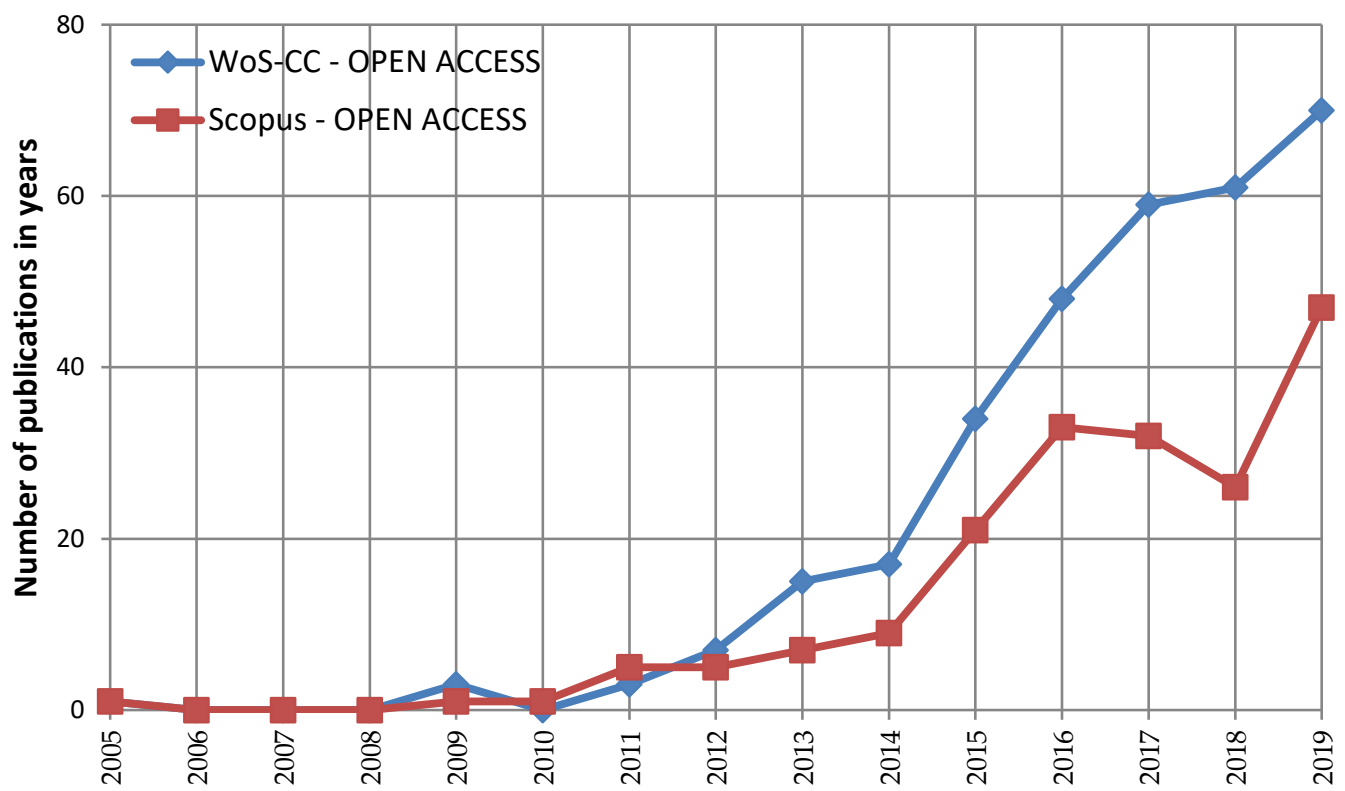

Figure 5. Number of articles in years indexed on WoS-CC and Scopus with Open Access license-2005-2019.

Table 1 shows the number of publications indexed in the WoS-CC and Scopus databases. It can be seen that in both cases most publications were published in Asia (China, South Korea, Republic of China), North America (USA, Canada), Europe (France, Poland).

Table 1. Number of articles in years indexed in WoS-CC and Scopus in countries.

\begin{tabular}{cccc}
\hline WoS-CC & Number of Articles & Scopus & Number of Articles \\
\hline China & 318 & China & 221 \\
USA & 289 & USA & 207 \\
Canada & 116 & South Korea & 84 \\
Republic of China & 95 & Canada & 82 \\
France & 72 & Republic of China & 75 \\
South Korea & 71 & Poland & 62 \\
Poland & 69 & France & 57 \\
Sweden & 63 & Malaysia & 55 \\
Japan & 62 & Brazil & 50 \\
Malaysia & 62 & Italy & 50 \\
\hline
\end{tabular}

Figure 6 shows the distribution of publications in the years for the 5 most relevant categories of Web of Science for the analyzed subject. Selected categories are: Energy Fuels (1059 doc.), Engineering Chemical (611 doc.), Agricultural Engineering (276 doc.), Biotechnology Applied Microbiology (267 doc.) and Thermodynamics (188 doc.). It can be seen that after 2009 there is an upward trend for all WoS-CC categories. The largest increase and also the largest total number of publications is in the Energy Fuels category. 


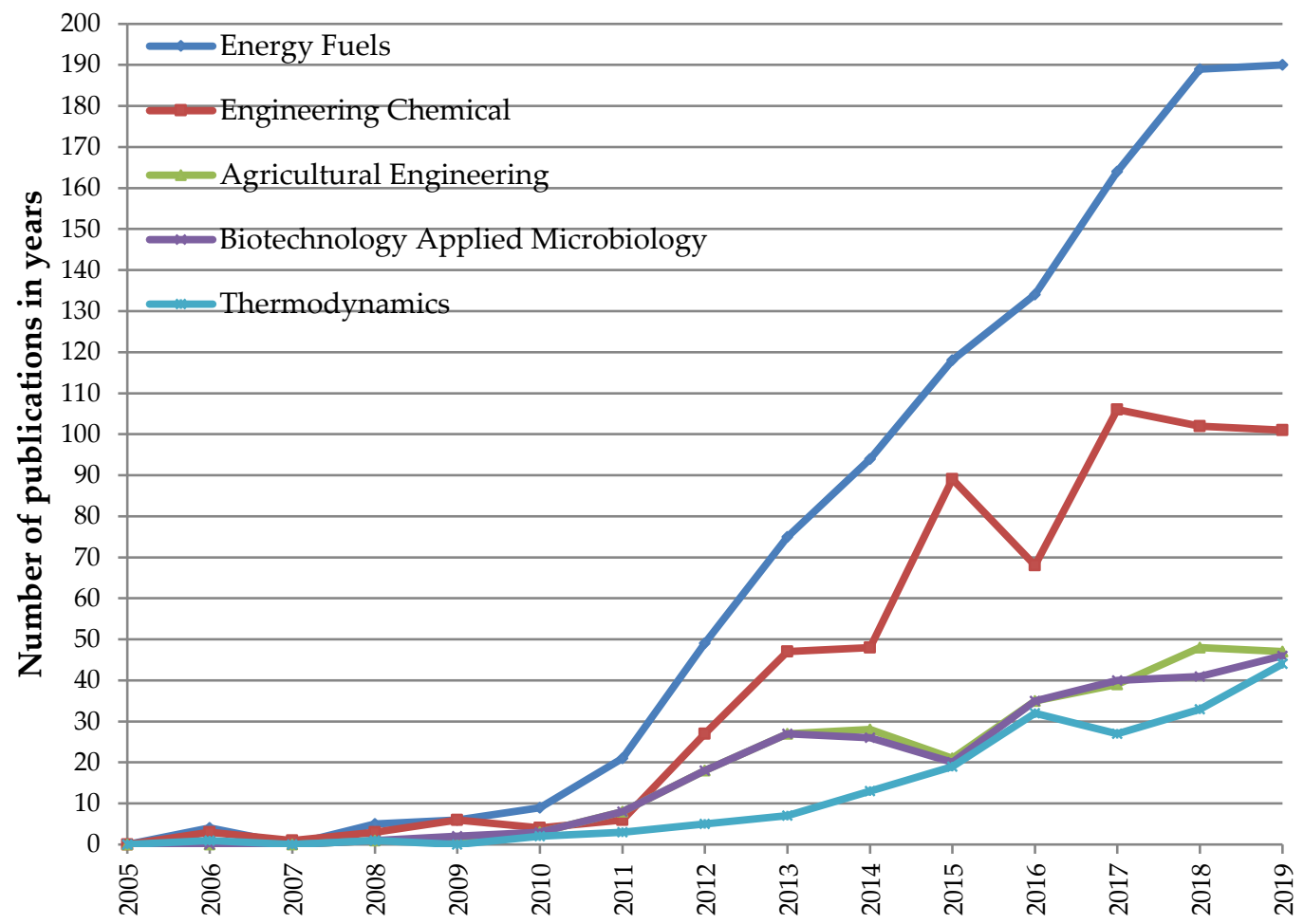

Figure 6. Number of articles in years indexed in WoS-CC in relation to the Web of Science category-2005-2019.

Figure 7 shows the distribution of publications in the years for the 5 most relevant Subject area in Scopus. Selected categories are: Energy (763 doc.), Chemical Engineering (528 doc.), Environmental Science (500 doc.), Engineering (301 doc.) and Chemistry (236 doc.). It can be seen that after 2010 there is an upward trend for all Subject area. The largest increase and also the largest total number of publications is in Energy Subject area.

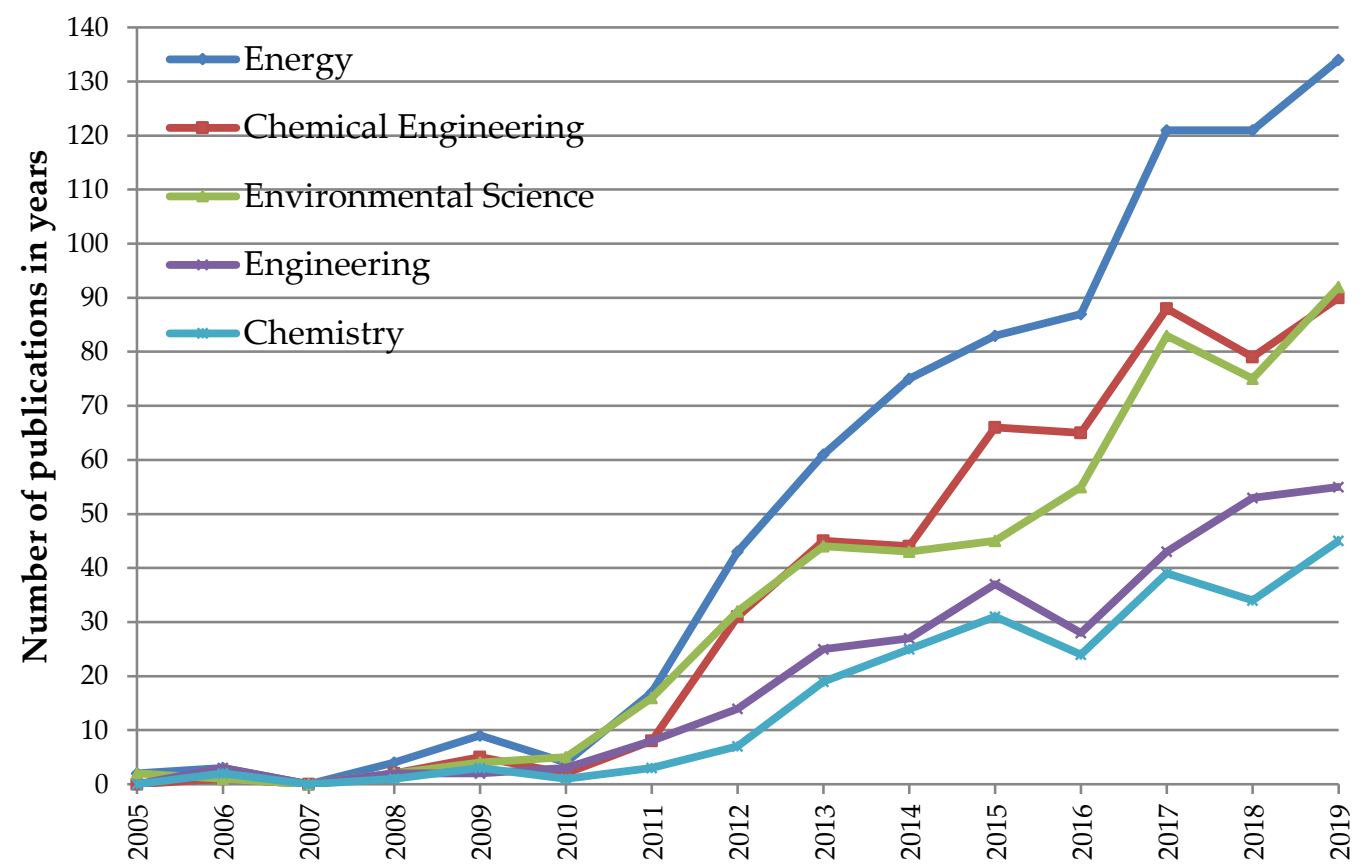

Figure 7. Number of articles in years indexed in Scopus in relation to the Subject area-2005-2019. 
The next stage was the keyword analysis for 2015-2019. Such analysis allows visualizing the relationships between keywords as well as analyzing these words over a selected period. In turn, keyword citation analysis allows to identify research topics of greatest interest to researchers

The first analysis concerned the incidence of keywords in years (Figure 8.). The colors represent individual years. 2015-2016 (dark blue/blue/light blue)- 'torrefaction', 'biomass', 'biochar', 'pyrolysis', 'combustion', 'biochar', 'pretreatment', 'kinetics'. 2017 (green)—'hydrothermal carbonization', 'wet torrefaction', 'fast pyrolysis', 'carbonization', 'co-combustion', 'slow pyrolysis', 'bioenergy', 'wood pellets', 'gasification'. 2018-2019 (yellow/orange/red)_-'fuel properties', 'risk husk', 'sewage sludge', 'torrefied biomass', 'biocoal', 'bio-oil'. One can notice the transition from torrefaction, pyrolysis, biomass combustion, analysis of selected parameters of biomass heat treatment processes, through new technologies (HTC), and ending with the search for new materials for torrefaction, e.g., sewage sludge, optimization of process parameters, testing of selected fuel properties.

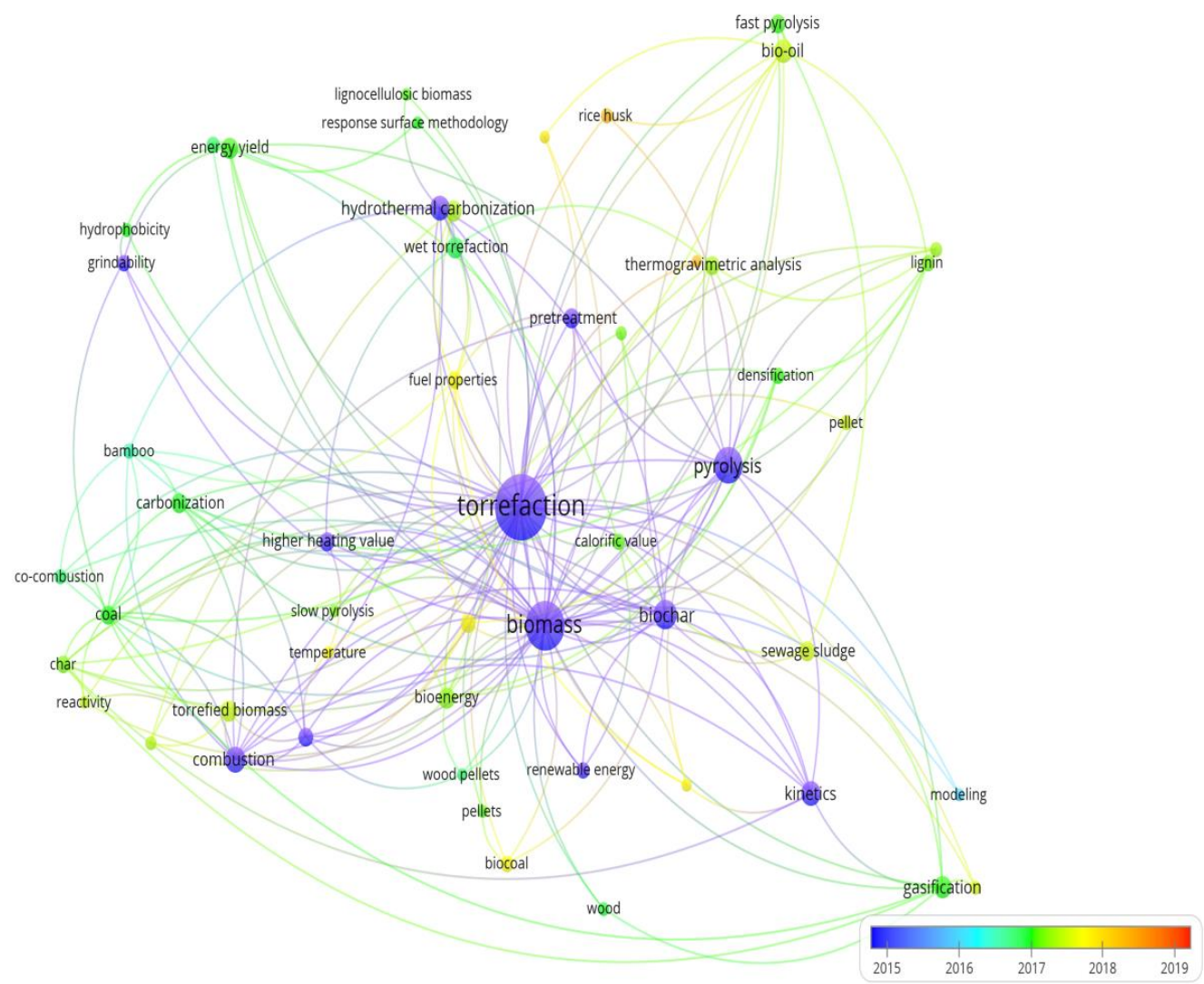

Figure 8. Map of term words for individual years—2015-2019.

The second thematic map (Figure 9) concerns the analysis of citations covered by topics/keywords. The closer the keywords are to orange/red, the higher the number of citations. The most recent keywords are: 'bioenergy', 'wood pellets', 'wet torrefaction', 'hydrothermal carbonization', 'hydrophobicity', 'densification', 'co-combustion' It can be stated that in the presented period (2015-2019), current research topics are new torrefaction technologies, such as HTC, research on improving the physico-mechanical and energy properties of produced fuel and the use of torrefied biomass in the pyrolysis and cocombustion process. 


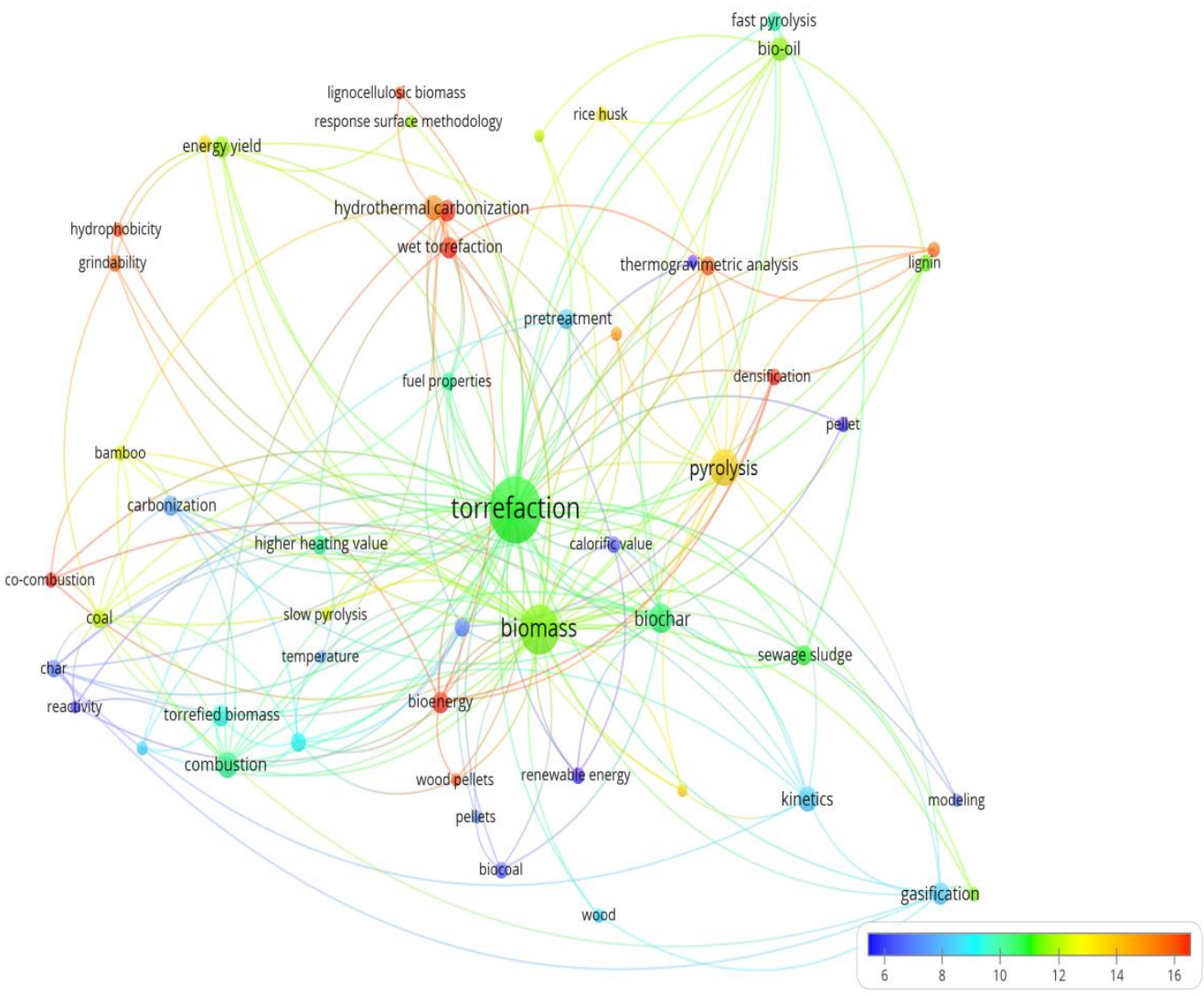

Figure 9. Map of term words with reference to citations-2015-2019.

\subsection{The Results of Qualitative-Thematic Analysis}

The second stage of research was a detailed thematic analysis of the publications in the Open Access license for the entire Wos-CC category 'Energy Fuels'-134 articles and Scopus Subject Area: 'Energy' -75 articles. Publications which were published mainly in journals such as: Energies, Biomass \& Bioenergy, Energy \& Fuels, Fuel and Applied Energy were analyzed. Groups such as torrefaction, hydrothermal carbonization (HTC), pyrolysis, gasification and others have been specified. In each of the groups, the torrefaction process was used as one of the components (end product, raw material or intermediate for further processing).

The first group concerned the analysis of the applications of the torrefaction process (Figure 10, Appendix A: Table A1). There were 62 publications in this group. 


\begin{tabular}{|c|c|c|}
\hline APPLICATION: & \multirow{7}{*}{ 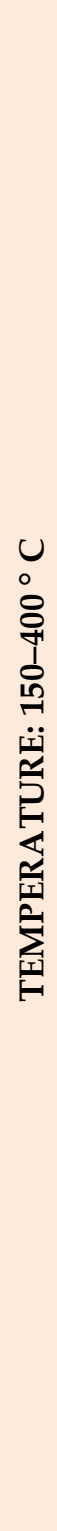 } & MATERIAL: \\
\hline $\begin{array}{l}\text { \# study of selected physical, mechanical parameters } \\
\text { (true density, grindability, hydrophobicity), selected } \\
\text { chemical parameters, selected energy parameters }\end{array}$ & & $\begin{array}{l}\text { \# waste from: a) food } \\
\text { processing (apple } \\
\text { pomace, currant pomace, } \\
\text { orange peel, walnut shell, }\end{array}$ \\
\hline $\begin{array}{l}\text { \# the impact of raw materials and mixed raw materials } \\
\text { on fuel properties (biomass, sewage sludge, waste } \\
\text { from food processing and agricultural production), } \\
\text { biochar addition on the biogas production kinetics }\end{array}$ & & $\begin{array}{l}\text { mushroom spent } \\
\text { compost, Brewer's spent } \\
\text { gain, grape seed cake, } \\
\text { sunflower seed shells, rice }\end{array}$ \\
\hline $\begin{array}{c}\text { \# the impact of selected process parameters } \\
\text { (temperature, torrefaction time, material fragmentation) } \\
\text { on fuel properties, kinetics of torrefaction process, } \\
\text { optimization of torrefaction process parameters and } \\
\text { comparison of different torrefaction process }\end{array}$ & & $\begin{array}{l}\text { b) agricultural } \\
\text { production (corn cobs, } \\
\text { corn stover, wheat straw, } \\
\text { rapeseed straw, palm } \\
\text { kernel shell), c) animal } \\
\text { (elephant dung) }\end{array}$ \\
\hline & & $\begin{array}{l}\text { \# processed wood (beech, } \\
\text { poplar, pine, birch, } \\
\text { spruce, cedar wood, ash, } \\
\text { aspen, sawdust, chips, } \\
\text { bark, stump, forest } \\
\text { residues) }\end{array}$ \\
\hline & & $\begin{array}{l}\text { \# sewage sludge and } \\
\text { municipal solid waste }\end{array}$ \\
\hline & & \# microalgae \\
\hline
\end{tabular}

Figure 10. Main research topics and process parameters-torrefaction process.

The second group concerned the hydrothermal carbonization (HTC) process and is presented in Figure 11 and Appendix A: Table A2. There are 10 publications in this group. 


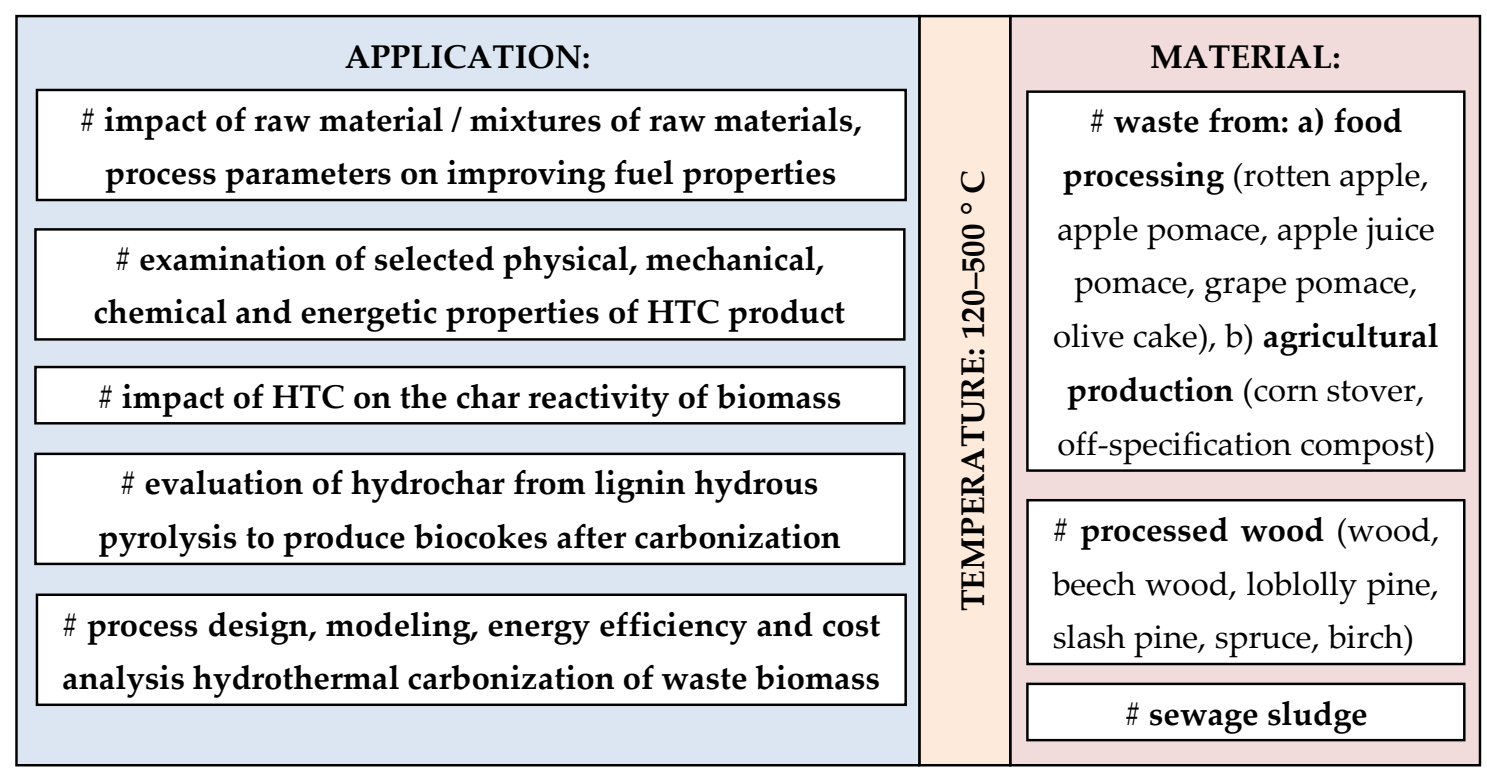

Figure 11. Main research topics and process parameters-the hydrothermal carbonization (HTC).

The third group concerned the use of torrefied biomass in the pyrolysis process (Figure 12, Appendix A: Table A3). There are 19 publications in this group.

\begin{tabular}{|c|c|c|}
\hline APPLICATION: & \multirow{7}{*}{ 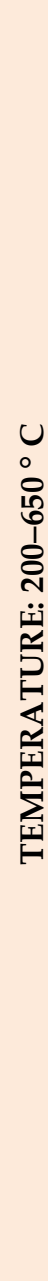 } & MATERIAL: \\
\hline $\begin{array}{c}\text { \# studies of selected physico-mechanical, chemical } \\
\text { and energy parameters }\end{array}$ & & $\begin{array}{l}\text { \# waste from: a) food } \\
\text { processing (food waste, }\end{array}$ \\
\hline $\begin{array}{l}\text { \# influence of pretreatment, kinetic study on the } \\
\text { pyrolysis process }\end{array}$ & & b) agricultural \\
\hline \multirow{4}{*}{$\begin{array}{c}\text { \# influence of pyrolysis process parameters, raw } \\
\text { material / mixtures of raw materials, comparison of } \\
\text { different pyrolysis technologies, modeling and } \\
\text { optimization of pyrolysis process parameterson fuel } \\
\text { properties } \\
\end{array}$} & & feed) \\
\hline & & $\begin{array}{l}\text { \# biomass: a) processed } \\
\text { wood (pine, softwood } \\
\text { bark, softwood lumber }\end{array}$ \\
\hline & & $\begin{array}{c}\text { spruce, mixed waste } \\
\text { wood, red oak, pine, } \\
\text { sawdust, chips, aspen, } \\
\text { lumber, debarked logs, } \\
\text { bark, foliage, douglas-fir, } \\
\text { birch, oak), b) energy } \\
\text { crops (willow, rye grass, } \\
\text { switchgrass), c) processed } \\
\text { wood from exotic plants } \\
\text { (rubber tree) }\end{array}$ \\
\hline & & \# sewage sludge \\
\hline
\end{tabular}

Figure 12. Main research topics and process parameters-pyrolysis group. 
The fourth group concerned the use of torrefied biomass in the gasification and cocombustion process (Figure 13, Appendix A: Table A4). There were 25 publications in this group.

\begin{tabular}{|c|c|c|}
\hline APPLICATION: & \multirow{8}{*}{ 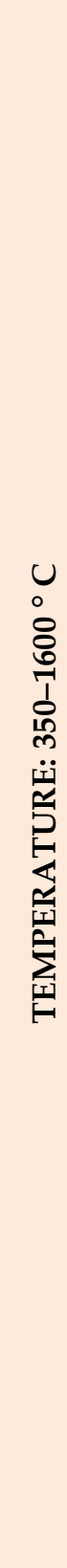 } & \multirow{8}{*}{$\begin{array}{c}\text { MATERIAL: } \\
\text { \# waste from: a) food } \\
\text { processing (palm kernel } \\
\text { shell, avocado pit, olive } \\
\text { stone, grape, olive } \\
\text { pomaces, cocoa shell, } \\
\text { sugarcane bagasse, oil } \\
\text { palm, chestnut, shell), } \\
\text { b) agricultural } \\
\text { production (wheat straw, } \\
\text { olive tree pruning, } \\
\text { Virginia mallow, rice } \\
\text { straw, cassava stalks, corn } \\
\text { cob) } \\
\text { \#iomass: a) processed } \\
\text { wood (spruce bark, } \\
\text { spruce, ash, pine wood, } \\
\text { pine sawdust, birch, } \\
\text { healthy pine, beetle kill } \\
\text { pine), b) energy crops } \\
\text { (miscanthus, willow, } \\
\text { napier grass), } \\
\text { c) processed wood from } \\
\text { exotic plants (eucalyptus, } \\
\text { bamboo), d) other } \\
\text { biomass (road side grass) } \\
\text { \# sewage sludge } \\
\end{array}$} \\
\hline $\begin{array}{c}\text { \# impact of pretreatment, raw materials / raw material } \\
\text { mixtures / coal, torrefaction on the process } \\
\text { performance on pyrolysis, gasification and } \\
\text { combustion }\end{array}$ & & \\
\hline \# comparison of different gasification technologies & & \\
\hline $\begin{array}{l}\text { \# influence of gasification process parameters, kinetic } \\
\text { study, modeling and optimization on fuel properties }\end{array}$ & & \\
\hline $\begin{array}{l}\text { \# design, optimization and energetic efficiency of } \\
\text { producing hydrogen-rich gas from biomass steam } \\
\text { gasification }\end{array}$ & & \\
\hline $\begin{array}{c}\text { \# characterizes the oxidation properties biomass char } \\
\text { and compare with that of raw biomass char }\end{array}$ & & \\
\hline & & \\
\hline & & \\
\hline
\end{tabular}

Figure 13. Main research topics and process parameters—gasification and co-combustion.

The last group concerned the other topics related to the process of thermal biomass processing, which thematically did not fit directly into the previously mentioned (Figure 14, Appendix A: Table A5). There were 35 publications in this group. 


\begin{tabular}{|c|c|}
\hline \multicolumn{2}{|c|}{ APPLICATION: } \\
\hline $\begin{array}{l}\text { \# process modeling and forecasting } \\
\text { integrated biomass torrefaction and }\end{array}$ & $\begin{array}{c}\text { \# carbon efficiency of the biomass to } \\
\text { liquid process }\end{array}$ \\
\hline pelletization (iBTP) & \multirow{2}{*}{$\begin{array}{c}\text { \# use of biomass in integrated } \\
\text { steelmaking }\end{array}$} \\
\hline \# the analysis integrated systems of & \\
\hline $\begin{array}{l}\text { electricity, heat, road transport, aviation } \\
\text { and chemicals in chosen countries }\end{array}$ & \multirow{2}{*}{$\begin{array}{c}\text { \# coupling of an acoustic emissions } \\
\text { system to a laboratory torrefaction } \\
\text { reactor }\end{array}$} \\
\hline \# analysis of domestic and international & \\
\hline $\begin{array}{l}\text { bioenergy supply chains for co-firing } \\
\text { plants }\end{array}$ & \multirow{2}{*}{$\begin{array}{l}\text { \# technical assessment of the Biomass } \\
\text { Integrated Gasification / Gas Turbine } \\
\text { Combined Cycle incorporation }\end{array}$} \\
\hline \# an LCA-based evaluation of biomass & \\
\hline $\begin{array}{l}\text { to transportation fuel production and } \\
\text { utilization }\end{array}$ & \multirow{2}{*}{$\begin{array}{c}\text { \# the role of bioenergy and } \\
\text { biochemicals in } \mathrm{CO}_{2} \text { mitigation through } \\
\text { the energy system }\end{array}$} \\
\hline \# a whole-systems analysis of the value & \\
\hline $\begin{array}{l}\text { chain associated with cultivation, } \\
\text { harvesting, transport and conversion in } \\
\text { dedicated biomass power stations }\end{array}$ & $\begin{array}{l}\text { \# economic impact of combined } \\
\text { torrefaction and pelletization processes } \\
\text { on forestry biomass supply }\end{array}$ \\
\hline $\begin{array}{l}\text { \# the climate contribution of biomass } \\
\text { co-combustion in a coal-fired power }\end{array}$ & $\begin{array}{c}\text { \# influence of mill type on densified } \\
\text { biomass comminution }\end{array}$ \\
\hline plant & \multirow{2}{*}{$\begin{array}{c}\text { \# an energy analysis comparing } \\
\text { biomass torrefaction in depots to wind } \\
\text { with natural gas combustion for } \\
\text { electricity generation }\end{array}$} \\
\hline $\begin{array}{c}\text { \# techno-economic and carbon } \\
\text { emissions analysis of biomass } \\
\text { torrefaction downstream in }\end{array}$ & \\
\hline for co-firing & \multirow{2}{*}{$\begin{array}{l}\text { \# optimal production scheduling for } \\
\text { energy efficiency improvement in } \\
\text { biofuel feedstock preprocessing }\end{array}$} \\
\hline$\#$ an assessment of the torrefaction of & \\
\hline greenhouse gas emission & \multirow{2}{*}{$\begin{array}{l}\text { \# optimization the minimum } \\
\text { production cost for the production of } \\
\text { woody biofuels }\end{array}$} \\
\hline \# prediction of high-temperature rapid & \\
\hline $\begin{array}{l}\text { combustion behaviour of woody } \\
\text { biomass particles }\end{array}$ & \multirow{2}{*}{$\begin{array}{c}\text { \# environmental and energy } \\
\text { performance of the biomass to synthetic } \\
\text { natural gas supply chain }\end{array}$} \\
\hline \# modeling of biofuel pellets & \\
\hline torrefaction in a realistic geometry & \multirow{3}{*}{$\begin{array}{l}\text { \# investigation into the applicability of } \\
\text { Bond Work Index (BWI) and Hardgrove } \\
\text { Grindability Index (HGI) tests for } \\
\text { several biomasses }\end{array}$} \\
\hline $\begin{array}{c}\text { \# Explosion characteristics of pulverised } \\
\text { torrefied and raw biomass }\end{array}$ & \\
\hline & \\
\hline
\end{tabular}

Figure 14. Main research topics-other topics. 


\section{Discussion}

Originally, the analysis of the literature was to be carried out within the torrefaction process area. In the course of a thorough analyses, it turned out that the various thermal biomass conversion processes appear together with torrefaction. It is therefore not possible to analyse their content without taking into account other thermal processes.

Quantitative analysis showed a clear upward trend in the number of publications after 2010 (all publications and in the Open Access license), as presented in Figures 4 and 5. The trends of the graphs indicate that the number of publications may be expected to increase significantly in the following years. At the stage of quantitative analysis, it is difficult to determine unambiguously what is the maximum ceiling for this parameter. A detailed qualitative analysis should bring us significantly closer to this answer. At this stage there are no significant leaders in these topics, but there are some regions that seems to most active at this field. Most scientists studying the selected topics come from China, USA, Canada, South Korea, Republic of China, Poland (WoS-CC and Scopus databases) as presented in Table 1. Interestingly, categorization according to WoS-CC shows various publication profiles (Figure 6). This indicates that the interest is not only in the fields of energy fuels or chemical engineering, but also in other branches, like agriculture, biotechnology, or microbiology. As the Scopus categorization gives similar results (Figure 7), this could be a very promising direction for research into these processes, not just in the fuel context. Importantly, the analysis of the keywords also indicated a change in the context of the use of the term torrefaction. Initially (2015-2017), it tended to appear in the context of pyrolysis and combustion, but in later years (2017 to 2019), it also appears in the context of new technologies such as HTC and also co-firing. The newest papers also cover waste and sewage sludge treatment

A significant progress in the number of publications on this subject is directly related to the increased interest of scientists working in the thermal processing field, not only of biomass, but also of other materials, including waste. The properties of biocarbon can also be an important catalyst for the interest of the scientific world. Over the years, the possibilities for using this product have increased significantly, and new possibilities are constantly emerging. This covers with increasing interests on this topics in other branches.

As a result of qualitative (thematic) analysis, a clear upward trend was demonstrated in the thematic groups: torrefaction and gasification and co-combustion (Figure 15). The main applications of biomass heat treatment in selected groups are:

- Torrefaction process (Figure 10, Appendix A: Table A1)—The authors mainly discussed topics such as the impact of torrefaction on the hydrophobic properties of fuel, analysis of chemical, energy, physico-mechanical parameters of biochar, kinetics of the torrefaction process, influence of torrefaction process parameters on the energy properties of fuel, the impact of biogas on the efficiency of anaerobic digestion, the impact of raw material/mixtures of raw materials on the effectiveness of the torrefaction process, the effect of addition of biochar on the agglomeration process, mass and energy balance analysis in a continuous torrefaction installation, optimization of torrefaction process parameters, comparison of different technologies used in the torrefaction process, comparison of selected properties of biochar to coal. The process temperatures ranged from $200-400{ }^{\circ} \mathrm{C}$. The materials used in torrefying were biomass of various origins. The main sources of biomass were: energy crops, wood from fast growing and exotic trees with varying degrees of processing, mixtures of torrefaction and biomass, agricultural waste, food industry waste, sewage sludge and microalgae.

- $\quad$ HTC process (Figure 11, Appendix A: Table A2) - The authors mainly discussed topics such as the impact of HTC on improving fuel energy properties, the impact of raw material and parameters on process efficiency, modeling and optimization of the HTC process, the impact of HTC on reactivity and combustion kinetics. The process temperatures were in the range of $120-500{ }^{\circ} \mathrm{C}$. The materials used in the hydrothermal carbonization process were biomass of various origins. The main sources of biomass 
were energy crops, wood with various degrees of processing, agricultural waste, food industry waste and sewage sludge.

- Pyrolysis process (Figure 12, Appendix A: Table A3)-The authors mainly discussed topics such as the impact of process parameters (temperature, time) on the chemical, energy and physical-mechanical properties of fuels, kinetic analysis of the pyrolysis process, production and characterization of bio-oil and biochar, activated carbon from the pyrolysis, biochar characteristics from biomass carbonization, process optimization. Process temperatures were in the range: $200-650{ }^{\circ} \mathrm{C}$. Materials used in torrefaction were biomass of various origin. The main sources of biomass were energy crops, wood with varying degrees of processing from fast-growing, fruit and exotic trees, agricultural waste, food industry waste and sewage sludge.

- Gasification and co-combustion process (Figure 13, Appendix A: Table A4)-The authors mainly discussed topics such as analysis of the kinetic process, process efficiency (proliferation, gasification, combustion), analysis of the co-combustion process of mixtures, e.g., sewage sludge, coal with biomass (biochar, raw), the impact of material changes (torrefaction, mixing of various raw materials) on the chemical, energy and physico-mechanical properties of fuels, process optimization. Process temperatures were in the range: $350-1600{ }^{\circ} \mathrm{C}$. Materials used in torrefaction were biomass of various origins. The main sources of biomass were energy crops, wood with varying degrees of processing from fast-growing, fruit and exotic trees, agricultural waste, food industry waste and sewage sludge. Blends of biomass with coal were also used.

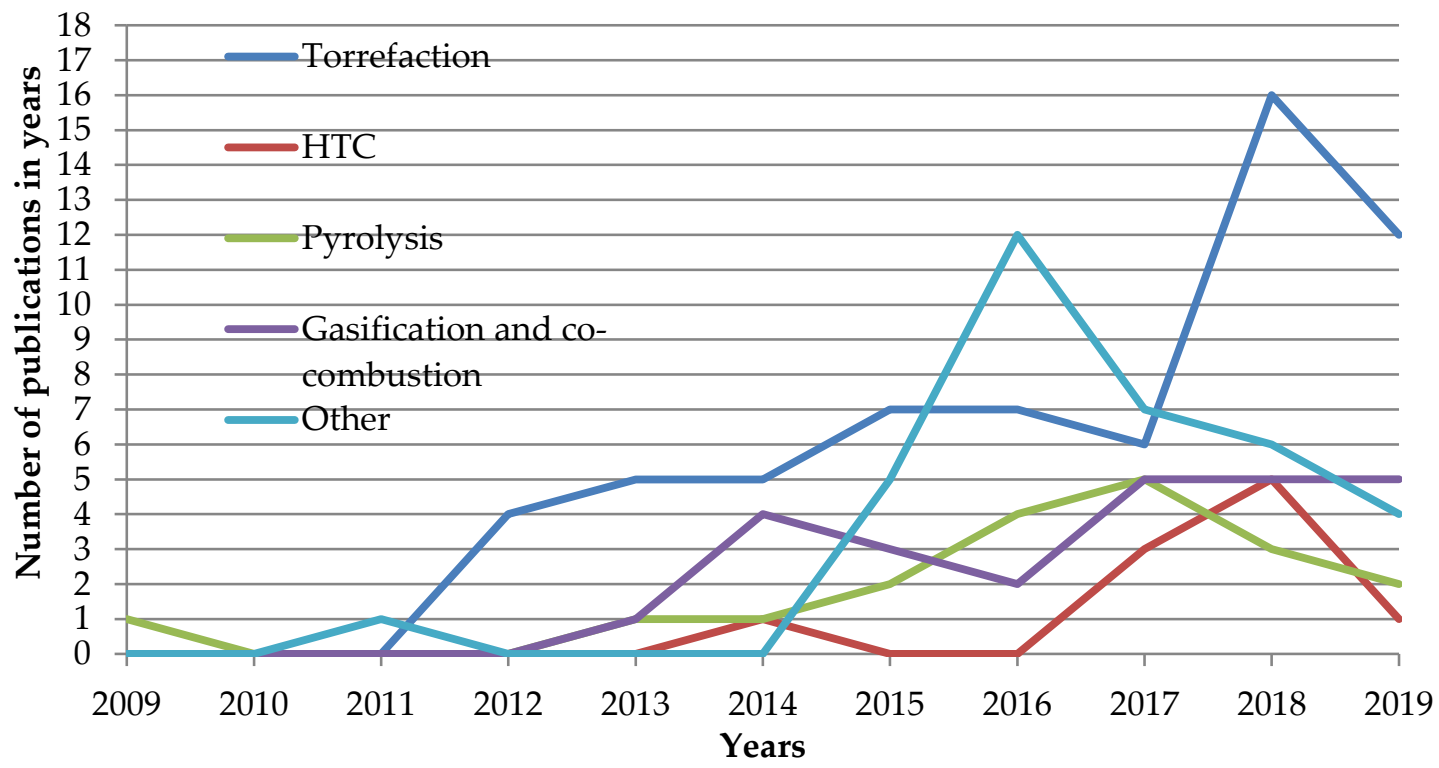

Figure 15. Number of articles in years in individual thematic groups.

Publications that did not fit thematically in the groups: torrefaction, HTC, pyrolysis, gasification and co-combustion were placed in the "other" group (Figure 14, Appendix A: Table A5). The main topics included regional analysis and global effectiveness of the use of torrefaction and biochar in the bioeconomy, analysis and optimization of the solid biofuels supply chain, analysis of integrated energy generation systems (biomass gasification, gas turbine and others) in selected areas of the economy, product life cycle analysis (LCA), technical and economic analyzes of the biomass torrefaction process in selected countries, optimization of production scheduling, forecasting and modeling of biomass thermal treatment processes, investigation into the applicability of the Bond Work Index (BWI) and Hardgrove Grindability Index (HGI) tests for several biomasses. 
To date, many review publications have been created covering a selected thematic area (67 documents-WoS-CC, 57 documents-Scopus). These articles are published in leading journals, and their usefulness is demonstrated by a large number of citations. Examples of thematic areas discussed: improvement of selected properties through the torrefaction process, analysis of the technologies used, indication of application areas $[65,66]$, application of thermochemical conversion for selected biological materials [67,68], co-combustion of coal with biomass, as well as biomass pretreatment in selected countries [69]. The results of this publication complement the current literature research with a comprehensive review of publications in the Open Access license in the scientific databases WoS-CC (WoS-CC category: Energy Fuels) and Scopus (Subject area: Energy).

All this information shows clearly that thermal processing of biomass, and in particular torrefaction is a promising technology, and in the next few years we can expect to see many papers about this process. Qualitative analysis shows that at this time, we cannot precisely forecast what the trends in the next years will be. For sure papers concerning torrefaction will more concentrated on the other branches than energy and fuels. Microbilology seems to be promising way, as trend analysis (Figures 6 and 7) shows potential to improvement in this category. Also production and biochar analysis seems to be still a very desired direction. Introduction of new materials, like waste biomass, or sewage sludge, seems to be next stage in research list of many scientists. As this topic is still new, there is big potential for good papers, which valuable will be evidenced by high citation scores.

Thanks to the holistic approach and cumulative presentation of results, this publication can be a valuable source of knowledge for researchers dealing with selected topics and industry. Especially in the latter area, trade and scientific magazines in the Open Access license are important because they can be an inspiration to implement innovative solutions and establish scientific cooperation.

\section{Conclusions}

(1) Thermal biomass processing is a current research topic. A clear upward trend in the number of publications after 2010 can be noticed. Quantitative analysis also showed that the most important categories of WoS-CC in the selected topic are: Energy Fuels, Engineering Chemical, Agricultural Engineering, Biotechnology Applied Microbiology and Thermodynamics and Scopus Subject area: Energy, Chemical Engineering, Environmental Science, Engineering and Chemistry.

(2) In 2015-2019, current research topics were: new torrefaction technologies (e.g., HTC), improvement of the physico-mechanical, chemical and energy properties of the fuel produced and the use of torrefied biomass in the processes of pyrolysis, gasification and co-combustion.

(3) The raw materials used in all types of heat treatment processes were energy crops, wood from fast-growing and exotic trees, waste from the agri-food industry, waste from agricultural production, sewage sludge and microalgae.

The thematic scope of the analyzed publications was very diverse. Four main thematic groups were identified: torrefaction process, HTC process, pyrolysis process and gasification and co-combustion process. In addition to research topics related to process analysis and optimization, improvement of chemical, energetic and physical-mechanical properties of fuel, properties of raw materials and their mixtures, the authors also discussed the topics of technical and economic analysis of the torrefaction process, LCA, analysis and optimization of the supply chain and investigation into the applicability of Bond Work Index (BWI) and Hardgrove Grindability Index (HGI) tests for several biomasses.

Author Contributions: Conceptualization, A.K. and S.F.; Methodology, A.K. and S.F.; Formal analysis, A.K. and S.F. and M.J.; Investigation, A.K. and S.F.; Resources, A.K. and S.F.; Data curation, A.K.; Writing-original draft preparation, A.K., S.F., A.Z. and R.F.; Writing-review and editing, A.K., S.F., M.J., A.Z. and R.F.; Visualization, A.K.; Supervision, S.F., M.J., A.Z. and R.F. All authors have read and agreed to the published version of the manuscript. 
Funding: Article processing charges were financed from the subsidy of the Ministry of Science and Higher Education for the Agricultural University of Hugo Kołłataj in Krakow for the year 2020.

Conflicts of Interest: The authors declare no conflict of interest.

\section{Appendix A}

Table A1. Torrefaction process—-detailed thematic analysis.

\begin{tabular}{|c|c|c|c|c|}
\hline Ref. & Year & Application & Process Temp. $\left({ }^{\circ} \mathrm{C}\right)$ & Material \\
\hline$[70]$ & 2019 & $\begin{array}{l}\text { - influence of the temperature of the } \\
\text { torrefaction on the hydrophobic properties of } \\
\text { waste biomass }\end{array}$ & $\begin{array}{c}200,220,240,260,280 \\
300\end{array}$ & $\begin{array}{l}\text { apple pomace, currant pomace, } \\
\text { orange peel, walnut shell, } \\
\text { pumpkin seeds }\end{array}$ \\
\hline$[71]$ & 2019 & $\begin{array}{l}\text { - fuel characteristics of biochars from } \\
\text { torrefaction (a.k.a., roasting or } \\
\text { low-temperature pyrolysis) of elephant dung } \\
\text { (manure) }\end{array}$ & $\begin{array}{c}200,220,240,260,280 \\
300\end{array}$ & elephant dung (manure) \\
\hline$[72]$ & 2019 & $\begin{array}{l}\text { - fuel characteristics of biochars from torrefied } \\
\text { wood sawdust in normal and vacuum } \\
\text { environments }\end{array}$ & $\begin{array}{c}200,220,240,260,280 \\
300\end{array}$ & wood sawdust \\
\hline [73] & 2019 & $\begin{array}{l}\text { - production of wood pellets mixed with } \\
\text { torrefied rice straw }\end{array}$ & 220,280 & $\begin{array}{l}\text { wood pellets mixed with torrefied } \\
\text { rice straw }\end{array}$ \\
\hline [74] & 2019 & $\begin{array}{l}\text { - production of hybrid sewage sludge fuel for } \\
\text { the effective management of sewage sludge } \\
\text { - concept of spent mushrooms compost }\end{array}$ & 250 & sewage sludge \\
\hline$[75]$ & 2019 & $\begin{array}{l}\text { torrefaction-studying the process kinetics and } \\
\text { the influence of temperature and duration on } \\
\text { the calorific value }\end{array}$ & $200-300$ & mushroom spent compost \\
\hline [76] & 2019 & $\begin{array}{l}\text { - physical and chemical properties, true } \\
\text { density, grindability and hydrophobicity of } \\
\text { Thar coal along with raw and torrefied corn } \\
\text { cob were investigated }\end{array}$ & $200,225,250,275,300$ & corn cobs \\
\hline [77] & 2019 & $\begin{array}{l}\text { - effects of automatic temperature control in } \\
\text { torrefaction and the use of additives in } \\
\text { pelletization }\end{array}$ & $250-320$ & wood chips from Japanese cedar \\
\hline [78] & 2019 & $\begin{array}{l}\text { - the effect of biochar addition on the biogas } \\
\text { production kinetics from the anaerobic } \\
\text { digestion of brewers' spent grain }\end{array}$ & $200-300$ & Brewer's spent grain \\
\hline [79] & 2019 & $\begin{array}{l}\text { - kinetics of torrefaction and determine the } \\
\text { effects of process temperature on fuel } \\
\text { properties of torrefied products (biochars) }\end{array}$ & $200-300$ & Sewage sludge \\
\hline$[80]$ & 2019 & $\begin{array}{l}\text { - a fundamental research on synchronized } \\
\text { torrefaction and pelleting of biomass }\end{array}$ & 200 & Corn stover, big bluestem \\
\hline$[81]$ & 2019 & $\begin{array}{l}\text { - the concept of carbonized refuse-derived } \\
\text { fuel (CRDF) by refuse-derived fuel (RDF) } \\
\text { torrefaction }\end{array}$ & $200-300$ & RDF \\
\hline$[82]$ & 2018 & $\begin{array}{l}\text { - impact fo biomass diversity on torrefaction } \\
\text { process }\end{array}$ & 200-300 & $\begin{array}{l}\text { ash-wood, beech, poplar, willow, } \\
\text { pine, pine forest residues, scot } \\
\text { pine bark, miscanthus, reed canary } \\
\text { grass, corn cob, grape seed cake, } \\
\text { sunflower seed shells, wheat straw } \\
\text { (French), wheat straw (Swedish) }\end{array}$ \\
\hline [83] & 2018 & $\begin{array}{l}\text { - ultrasonic pelleting of torrefied biomass for } \\
\text { bioenergy production }\end{array}$ & $200-300$ & wheat straw \\
\hline [84] & 2018 & $\begin{array}{l}\text { - energetic properties of torrefied and raw } \\
\text { wheat straw, rapeseed, and willow }\end{array}$ & $220,260,300$ & $\begin{array}{c}\text { willow, rapeseed straw, wheat } \\
\text { straw }\end{array}$ \\
\hline [85] & 2018 & - densification of torrefied refuse-derived fuel & 260 & municipal solid waste \\
\hline [86] & 2018 & $\begin{array}{l}\text { - correlations to predict elemental } \\
\text { compositions and heating value of torrefied } \\
\text { biomass }\end{array}$ & $200-300$ & $\begin{array}{c}\text { birch, spruce, willlow, beech wood, } \\
\text { lauan, wood mixture, black locust, } \\
\text { pine, eucalyptus, poplar, } \\
\text { leaucaena, sawdust, cedar wood, } \\
\text { ash, aspen }\end{array}$ \\
\hline
\end{tabular}


Table A1. Cont.

\begin{tabular}{|c|c|c|c|c|}
\hline Ref. & Year & Application & Process Temp. $\left({ }^{\circ} \mathrm{C}\right)$ & Material \\
\hline [87] & 2018 & $\begin{array}{l}\text { - torrefaction of manually pressed and liquid } \\
\text { nitrogen treated of microalgae for bioenergy } \\
\text { utilisation }\end{array}$ & 200,300 & microalgae \\
\hline [88] & 2018 & $\begin{array}{l}\text { - production upgraded wood fuel by } \\
\text { torrefaction }\end{array}$ & $200-300$ & raw Japanese cedar chips \\
\hline [89] & 2018 & $\begin{array}{l}\text { - properties of product biomass torrefaction } \\
\text { based on three major components: } \\
\text { hemicellulose, cellulose, lignin }\end{array}$ & $210,240,270,300$ & $\begin{array}{c}\text { microcrystalline cellulose, } \\
\text { beechwood xylan (representative } \\
\text { of hemicellulose), alkali lignin }\end{array}$ \\
\hline$[90]$ & 2018 & $\begin{array}{l}\text { - properties of torrefied waste blends } \\
\text { - investigate the optimal temperature range }\end{array}$ & 300 & paper fiber, plastic waste \\
\hline$[91]$ & 2018 & $\begin{array}{l}\text { for waste Wood and the effect torrefaction } \\
\text { residence time had on torrefied biomass } \\
\text { feedstock }\end{array}$ & $200-400$ & wood waste \\
\hline$[92]$ & 2018 & $\begin{array}{l}\text { - analyses of torrefied biomass of tropical } \\
\text { plantation species }\end{array}$ & $200,225,250$ & $\begin{array}{l}\text { cupressus lusitanica, dipteryx } \\
\text { panamensis, gmelina arborea, } \\
\text { tectona grandis and vochysia } \\
\text { ferruginea }\end{array}$ \\
\hline [93] & 2018 & $\begin{array}{l}\text { - concept an installation for sustainable } \\
\text { thermal utilization of sewage sludge }\end{array}$ & 300 & sewage sludge \\
\hline$[94]$ & 2018 & $\begin{array}{l}\text { - the impact of residence time, temperature, } \\
\text { and particle size on torrefied rice husk, using } \\
\text { a bench-scale batch reactor }\end{array}$ & 240-295 & rice husk \\
\hline$[95]$ & 2018 & $\begin{array}{l}\text { - the effect of different parameters were } \\
\text { investigated on two abundant sources of } \\
\text { biomass in South Africa }\end{array}$ & $200-300$ & marula seeds, blue gum wood \\
\hline$[96]$ & 2018 & $\begin{array}{l}\text { - Solid fuel characterization of torrefied } \\
\text { coconut shells in an oxidative environment }\end{array}$ & $250-300$ & Local coconut Shell chips \\
\hline [97] & 2018 & $\begin{array}{l}\text { - effects of torrefaction on fuel properties of } \\
\text { solid and condensate products }\end{array}$ & $200-300$ & Cogon grass \\
\hline$[98]$ & 2017 & $\begin{array}{l}\text { - comparative study on the thermal behavior } \\
\text { of raw and torrefied bark, stem wood, stump } \\
\text { of Norway spruce. }\end{array}$ & $225,275,300$ & $\begin{array}{l}\text { Norway spruce (stem wood, bark, } \\
\text { stump) }\end{array}$ \\
\hline [99] & 2017 & $\begin{array}{l}\text { - physical and compression properties of } \\
\text { pellets manufactured with the torrefied } \\
\text { biomass of woody tropical species }\end{array}$ & $200,225,250$ & $\begin{array}{l}\text { cupressus lusitanica, dipterix } \\
\text { panamensis, gmelina arborea, } \\
\text { tectona grandis, vochysia } \\
\text { ferruginea }\end{array}$ \\
\hline [100] & 2017 & $\begin{array}{l}\text { - Preliminary production test of torrefied } \\
\text { woody biomass fuel in a small scale plant. }\end{array}$ & 215 & Japanese cedar \\
\hline [101] & 2017 & $\begin{array}{l}\text { - production of torrefied solid biofuel from } \\
\text { pulp industry waste }\end{array}$ & $260,280,300,320$ & wood waste with pulp sludge \\
\hline [102] & 2017 & - fuel properties of torrefied sorghum biomass & $250,275,300$ & sorghum, sweet sorghum bagasse \\
\hline [103] & 2017 & $\begin{array}{l}\text { - energy densification of animal waste, corn } \\
\text { cob and pine wood }\end{array}$ & $200,250,300$ & Cow dung, corn cob, pine wood \\
\hline [104] & 2016 & $\begin{array}{l}\text { - production of solid fuel from torrefied } \\
\text { coconut leaves }\end{array}$ & $245-295$ & coconut leaves \\
\hline [105] & 2016 & $\begin{array}{l}\text { - comparing grindability of different torrefied } \\
\text { biomass pellets in different laboratory mills }\end{array}$ & 260,308 & $\begin{array}{l}\text { forest residues, willow, pine, } \\
\text { poplar, spruce, beech, straw }\end{array}$ \\
\hline [106] & 2016 & $\begin{array}{l}\text { - compositional study of torrefied wood and } \\
\text { herbaceous materials by chemical analysis } \\
\text { and thermoanalytical methods }\end{array}$ & $200,225,250,270,300$ & $\begin{array}{l}\text { black locust wood, wheat and rape } \\
\text { straw }\end{array}$ \\
\hline [107] & 2016 & $\begin{array}{l}\text { - thermal desorption of wood railroad ties } \\
\text { - detailed mapping of the mass and energy }\end{array}$ & $250,275,300,325,350$ & creosote-treated wood \\
\hline [108] & 2016 & $\begin{array}{l}\text { balance of a continuous biomass torrefaction } \\
\text { plant }\end{array}$ & $250-265$ & spruce, ash, willow \\
\hline [109] & 2016 & $\begin{array}{l}\text { - thermochemical and structural changes in } \\
\text { Jatropha curcas seed cake during torrefaction } \\
\text { for its use as coal co-firing feedstock }\end{array}$ & $200-300$ & jatropha curcas \\
\hline [110] & 2016 & $\begin{array}{l}\text { - biochemical conversion of torrefied norway } \\
\text { spruce after pretreatment with acid or ionic } \\
\text { liquid }\end{array}$ & $260-310$ & Norway spruce \\
\hline
\end{tabular}


Table A1. Cont.

\begin{tabular}{|c|c|c|c|c|}
\hline Ref. & Year & Application & Process Temp. $\left({ }^{\circ} \mathrm{C}\right)$ & Material \\
\hline [111] & 2015 & $\begin{array}{l}\text { - identification and quantification of the } \\
\text { condensable species released during } \\
\text { torrefaction of lignocellulosic biomass }\end{array}$ & $250,280,300$ & $\begin{array}{l}\text { pine, ash wood, miscanthus, } \\
\text { wheat straw }\end{array}$ \\
\hline [112] & 2015 & $\begin{array}{l}\text { - evaluation of solvent for pressurized liquid } \\
\text { extraction in torrefied woody biomass }\end{array}$ & 270,300 & eucalyptus wood chips \\
\hline [113] & 2015 & $\begin{array}{l}\text { - study on dry torrefaction of beech wood and } \\
\text { miscanthus }\end{array}$ & $240,260,280,300$ & beech wood, miscnathus (sinensis) \\
\hline [114] & 2015 & $\begin{array}{l}\text { - composition, utilization and economic } \\
\text { assessment of torrefaction condensates }\end{array}$ & $200-300$ & spruce, bamboo \\
\hline [115] & 2015 & $\begin{array}{l}\text { - analysis on storage off-gas emissions from } \\
\text { woody, herbaceous and torrefied biomass }\end{array}$ & 250 & Switchgrass (Panicum virgatum) \\
\hline [116] & 2015 & $\begin{array}{l}\text { - qualitative and kinetic analysis of } \\
\text { torrefaction of lignocellulosic biomass }\end{array}$ & $200,275,300$ & miscanthus, wheat straw \\
\hline [117] & 2015 & $\begin{array}{l}\text { - comparison of chemical composition and } \\
\text { energy Property of Torrefied switchgrass and } \\
\text { corn stover }\end{array}$ & $180-270$ & switchgrass, corn stover \\
\hline [118] & 2014 & $\begin{array}{l}\text { - the effects of torrefaction on the basic } \\
\text { characteristics of corn stalks }\end{array}$ & $150-400$ & corn stalks \\
\hline [119] & 2014 & $\begin{array}{l}\text { - decomposition kinetics of torrefaction of } \\
\text { some nigerial lignocellulosic biomass }\end{array}$ & $240,270,300$ & $\begin{array}{c}\text { albizia pedicellaris, tectona } \\
\text { grandis, terminalia ivorensis, } \\
\text { sorghum bicolour glume, sorghum } \\
\text { bicolour stalk }\end{array}$ \\
\hline [120] & 2014 & $\begin{array}{l}\text { - process simulation of co-firing torrefied } \\
\text { biomas in a } 220 \text { Mwe coal-fired power plant }\end{array}$ & $200,250,270,300$ & palm kernel shell \\
\hline [121] & 2014 & $\begin{array}{l}\text { - process evaluation for torrefaction of empty } \\
\text { fruit bunch from palm oil mill }\end{array}$ & 300 & $\begin{array}{l}\text { empty fruit bunch (EFB) from } \\
\text { Malaysian palm oil mill }\end{array}$ \\
\hline [122] & 2014 & $\begin{array}{l}\text { - investigates the product yields and the solid } \\
\text { product characteristics from corncob waste } \\
\text { torrefaction }\end{array}$ & 250,300 & corncob waste \\
\hline [123] & 2013 & $\begin{array}{l}\text { - analysis of efficiency simultaneous } \\
\text { torrefaction and grinding of biomass. }\end{array}$ & $240-330$ & $\begin{array}{l}\text { Danish wheat straw, Danish } \\
\text { spruce chips, Spanish pine chips }\end{array}$ \\
\hline [124] & 2013 & $\begin{array}{l}\text { - the influence of the chemical properties } \\
\text { (lignocellulose composition and alkali } \\
\text { content) on the torrefaction behavior with } \\
\text { respect to mass loss and grindability }\end{array}$ & 270,300 & $\begin{array}{l}\text { Danish wheat straw, miscanthus, } \\
\text { spruce wood chips, beech wood } \\
\text { chips, pine wood chips, spruce } \\
\text { bark }\end{array}$ \\
\hline [125] & 2013 & $\begin{array}{l}\text { - thermal decomposition kinetics of woods } \\
\text { - comparison of energy properties torrefaction }\end{array}$ & $200,225,250,275,300$ & Norwegian spruce, birch wood \\
\hline [126] & 2013 & $\begin{array}{l}\text { by microwave and conventional slow } \\
\text { pyrolysis }\end{array}$ & $200,230,250,300,350$ & willow \\
\hline [127] & 2013 & $\begin{array}{l}\text { - kinetic behavior of torrefied biomass in } \\
\text { oxidative environment }\end{array}$ & 225,275 & birch, spruce \\
\hline [128] & 2012 & $\begin{array}{l}\text { - chemical compositional changes during } \\
\text { torrefaction miscanthus and white oak } \\
\text { sawdust }\end{array}$ & $220-350$ & miscanthus, white oak \\
\hline [129] & 2012 & $\begin{array}{l}\text { - impact biomass torrefaction under different } \\
\text { oxygen concetration on composition of the } \\
\text { solid by-product }\end{array}$ & 240. 280 & eucalyptus grandis \\
\hline [130] & 2012 & $\begin{array}{l}\text { - the effects of particle size, different corn } \\
\text { stover components, and gas residence time on } \\
\text { torrefaction of corn stover }\end{array}$ & 250,280 & corn stover (Zea mays) \\
\hline [131] & 2012 & $\begin{array}{l}\text { - effect of torrefaction on water vapor } \\
\text { adsorption properties and resistance to } \\
\text { microbial degradation of corn stover }\end{array}$ & $200,250,300$ & corn stover \\
\hline
\end{tabular}


Table A2. Hydrothermal carbonization (HTC)—detailed thematic analysis.

\begin{tabular}{|c|c|c|c|c|}
\hline Ref. & Year & Application & Process Temp. $\left({ }^{\circ} \mathrm{C}\right)$ & Material \\
\hline [132] & 2019 & $\begin{array}{l}\text { - improvement of corn stover fuel properties } \\
\text { via hydrothermal carbonization }\end{array}$ & $120-280$ & corn stover \\
\hline [39] & 2018 & $\begin{array}{l}\text { - hydrothermal carbonization of peat moss } \\
\text { and herbaceous biomass (miscanthus) }\end{array}$ & 240 & peat moss; miscanthus \\
\hline [133] & 2018 & $\begin{array}{l}\text { - hydrothermal carbonization of biosolids } \\
\text { from waste water treatment plant }\end{array}$ & $180,200,220$ & sewage sludge \\
\hline [134] & 2018 & - hydrothermal carbonization of fruit wastes & $190,225,260$ & $\begin{array}{l}\text { rotten apple, apple chip pomace, } \\
\text { apple juice pomace, grape pomace }\end{array}$ \\
\hline [135] & 2018 & $\begin{array}{l}\text { - the impact of hydrothermal carbonisation on } \\
\text { the char reactivity of biomass }\end{array}$ & 200,225 & wood, olive cake \\
\hline [136] & 2018 & $\begin{array}{l}\text { - impact feedstock, reaction conditions and } \\
\text { post-treatment on properties of hydrochar } \\
\text { - evaluation of hydrochars from lignin }\end{array}$ & $180,220,250$ & wheat straw, beech wood \\
\hline [137] & 2017 & $\begin{array}{l}\text { hydrous pyrolysis to produce biocokes after } \\
\text { carbonization }\end{array}$ & $250,300,330-500$ & the pine kraft lignin \\
\hline [138] & 2017 & $\begin{array}{l}\text { - hydrothermal carbonization of loblolly pine } \\
\text { using a continuous, reactive twin-screw } \\
\text { extruder }\end{array}$ & $\begin{array}{c}200,215,235,255,260 \\
275,290,295\end{array}$ & loblolly pine, slash pine \\
\hline [139] & 2017 & $\begin{array}{l}\text { - process design, modeling, energy efficiency } \\
\text { and cost analysis hydrothermal carbonization } \\
\text { of waste biomass }\end{array}$ & $180,220,250$ & $\begin{array}{l}\text { off-specification compost, grape } \\
\text { marc }\end{array}$ \\
\hline [140] & 2014 & $\begin{array}{l}\text { - effects of wet torrefaction on reactivity and } \\
\text { kinetics of wood under air combustion } \\
\text { conditions }\end{array}$ & $175,200,225$ & Norway spruce, birch \\
\hline
\end{tabular}

Table A3. The use of torrefied biomass in the pyrolysis process-detailed thematic analysis.

\begin{tabular}{|c|c|c|c|c|}
\hline Ref. & Year & Application & Process Temp. $\left({ }^{\circ} \mathrm{C}\right)$ & Material \\
\hline [141] & 2019 & $\begin{array}{l}\text { - effects of pyrolysis temperature and retention } \\
\text { time on fuel characteristics of food waste feedstuff } \\
\text { and compost for co-firing in coal power plants }\end{array}$ & $300-500$ & food waste, compost, feed \\
\hline [142] & 2019 & $\begin{array}{l}\text { - combined organic acid leaching and torrefaction } \\
\text { as pine wood pretreatment before fast pyrolysis }\end{array}$ & 530 & pine wood \\
\hline [143] & 2018 & $\begin{array}{l}\text { - expedient prediction of the fuel properties of } \\
\text { carbonized woody biomass based on hue angle }\end{array}$ & $300-410$ & $\begin{array}{l}\text { rubber tree, softwood bark, } \\
\text { softwood lumber waste }\end{array}$ \\
\hline [144] & 2018 & $\begin{array}{l}\text { - energy and exergy analyses of sewage sludge } \\
\text { thermochemical treatment }\end{array}$ & $250,275,480,530$ & sewage sludge \\
\hline [145] & 2018 & $\begin{array}{l}\text { - impact of thermal pretreatment temperatures on } \\
\text { woody biomass chemical composition, physical } \\
\text { properties and microstructure }\end{array}$ & $\begin{array}{c}220,260,300,350,450 \\
550\end{array}$ & cherry wood \\
\hline [146] & 2017 & $\begin{array}{l}\text { - compared fast pyrolysis experiments of raw and } \\
\text { torreried woody biomass feedstocks. }\end{array}$ & $250-300,500$ & ash, spruce, mixed waste wood \\
\hline [147] & 2017 & $\begin{array}{l}\text { - staged thermal fractionation for segregation of } \\
\text { lignin and cellulose pyrolysis products }\end{array}$ & $\begin{array}{l}\text { 250. } 275,300-400, \\
500-600\end{array}$ & red oak \\
\hline [148] & 2017 & $\begin{array}{l}\text { - thermal decomposition kinetics of wood and bark } \\
\text { and their torrefied products }\end{array}$ & $225-450$ & Norway spruce \\
\hline [149] & 2017 & $\begin{array}{l}\text { - combined heat and power from the intermediate } \\
\text { pyrolysis of biomass materials }\end{array}$ & $450-550$ & $\begin{array}{l}\text { wood feedstock-pine } \\
\text { sawdust or ground pine chips }\end{array}$ \\
\hline [150] & 2017 & $\begin{array}{l}\text { - evolution of chars during slow pyrolysis of citrus } \\
\text { waste }\end{array}$ & $200-650$ & citrus waste \\
\hline [151] & 2016 & $\begin{array}{l}\text { - the effect of torrefaction temperature and time on } \\
\text { pyrolysis of centimeter-scale pine wood particles }\end{array}$ & $225,250,275,300,520$ & pine wood cuboid \\
\hline [152] & 2016 & $\begin{array}{l}\text { - mild hydrothermmal conditioning prior to } \\
\text { torrefaction and slow pyrolysis of low-value } \\
\text { biomass }\end{array}$ & 300,600 & willow, rye grass \\
\hline [153] & 2016 & $\begin{array}{l}\text { - thermal desorption of creosote remaining in used } \\
\text { railroad ties }\end{array}$ & $200,250,280,300,450$ & red oak, quercus rubra \\
\hline
\end{tabular}


Table A3. Cont.

\begin{tabular}{|c|c|c|c|c|}
\hline Ref. & Year & Application & Process Temp. $\left({ }^{\circ} \mathrm{C}\right)$ & Material \\
\hline [154] & 2016 & $\begin{array}{l}\text { - Effect of torrefaction temperature on lignin } \\
\text { macromolecule and product distribution from } \\
\text { catalytic pyrolysis }\end{array}$ & 500 & The southern pine, switchgrass \\
\hline [155] & 2015 & - unified kinetic model for torrefaction-pyrolysis & $\begin{array}{l}260,280,300,315,330 \\
375,400,425\end{array}$ & aspen wood \\
\hline [156] & 2015 & $\begin{array}{l}\text { - production and characterization of bio-oil and } \\
\text { biochar from the pyrolysis of fesidual bacterial } \\
\text { biomass from a polyhydroxyalkanoate production } \\
\text { process }\end{array}$ & 550 & residual bacterial biomass \\
\hline [157] & 2014 & $\begin{array}{l}\text { - characterization of biochar from switchgrass } \\
\text { carbonization }\end{array}$ & $300,350,400$ & switchgrass \\
\hline [158] & 2013 & $\begin{array}{l}\text { - a comparison of producer gas, biochar, and } \\
\text { activated carbon from two distributed scale } \\
\text { thermochemical conversion systems used to } \\
\text { process forest biomass }\end{array}$ & $350-750$ & $\begin{array}{l}\text { lumber, debarked logs, bark, } \\
\text { foliage, douglas-fir, lodgepole } \\
\text { pine }\end{array}$ \\
\hline [159] & 2009 & $\begin{array}{l}\text { - kinetic study on thermal decomposition of woods } \\
\text { in oxidative environment }\end{array}$ & $220-590$ & aspens, birch, oak, pine \\
\hline
\end{tabular}

Table A4. The use of torrefied biomass in the gasification and co-combustion process-detailed thematic analysis.

\begin{tabular}{|c|c|c|c|c|}
\hline Ref. & Year & Application & Process Temp. $\left({ }^{\circ} \mathrm{C}\right)$ & Material \\
\hline [160] & 2019 & $\begin{array}{l}\text { - combustion improvements of upgraded biomass } \\
\text { by washing and torrefaction }\end{array}$ & $1400-1600$ & $\begin{array}{l}\text { road side grass, miscanthus, } \\
\text { wheat straw, spruce bark }\end{array}$ \\
\hline [161] & 2019 & $\begin{array}{l}\text { - thermal analysis of olive tree pruning and the } \\
\text { by-products obtained by its gasification and } \\
\text { pyrolysis }\end{array}$ & 550,900 & olive tree pruning \\
\hline [162] & 2019 & $\begin{array}{l}\text { - theoretical and experimental analysis on } \\
\text { co-gasification of sewage sludge with energetic } \\
\text { crops }\end{array}$ & 950 & $\begin{array}{l}\text { sewage sludge, virginia } \\
\text { mallow }\end{array}$ \\
\hline [163] & 2019 & $\begin{array}{l}\text { - torrefaction as a valorization method used prior to } \\
\text { the gasification of sewage sludge }\end{array}$ & $350-900$ & sewage sludge \\
\hline [164] & 2019 & $\begin{array}{l}\text { - Influence of microwave pre-treated Palm Kernel } \\
\text { Shell and Mukah Balingian coal on co-gasification }\end{array}$ & $50.2-470.4$ & palm kernel shell \\
\hline [165] & 2018 & $\begin{array}{l}\text { - high temperature gasification of high heating-rate } \\
\text { chars using a flat-flame reactor. }\end{array}$ & 1300 & Norway spruce \\
\hline [166] & 2018 & $\begin{array}{l}\text { - analyzed the possibility of co-firing a series of } \\
\text { avocado biomass samples carbonized with coal. }\end{array}$ & $400,500,600$ & avocado pit \\
\hline [167] & 2018 & $\begin{array}{l}\text { - torrefaction of healthy and beetle kill pine and } \\
\text { co-combustion with sub-bituminous coal }\end{array}$ & 500 & healthy pine, beetle kill pine \\
\hline [168] & 2018 & $\begin{array}{l}\text { - coupled effect of torrefaction and blending on } \\
\text { chemical and energy properties for combustion }\end{array}$ & 900 & $\begin{array}{l}\text { napier grass, rice straw, } \\
\text { cassava stalks, corn cob }\end{array}$ \\
\hline [169] & 2018 & $\begin{array}{l}\text { - co-gasification of pine and oak biochar with } \\
\text { sub-bituminous coal in carbon dioxide }\end{array}$ & $833,900,975$ & $\begin{array}{l}\text { pine biochar, oak biochar, coal, } \\
\text { pine biochar-coal blend, oak } \\
\text { biochar-coal blend }\end{array}$ \\
\hline [170] & 2017 & $\begin{array}{l}\text { - effect of torrefaction on the process performance } \\
\text { of gasification of hardwood and softwood }\end{array}$ & 850 & spruce, ash \\
\hline [171] & 2017 & $\begin{array}{l}\text { - CFB gasification of commercial torrefied wood } \\
\text { pellets }\end{array}$ & $800-850$ & wood, \\
\hline [172] & 2017 & $\begin{array}{l}\text { - Organic carbon emissions from the co-firing of } \\
\text { coal and Wood in a fixe Bed combustor }\end{array}$ & 400 & pine wood, pine sawdust \\
\hline [173] & 2017 & $\begin{array}{l}\text { - optimization of a bubbling fluidized bed plant for } \\
\text { low-temperature gasification of biomass }\end{array}$ & 900 & $\begin{array}{l}\text { pine, chestnut, shell, olive } \\
\text { stone, grape, olive pomaces, } \\
\text { cocoa shell }\end{array}$ \\
\hline [174] & 2017 & $\begin{array}{l}\text { - The effect of torrefaction on syngas quality metrics } \\
\text { from fluidized bed gasification of SRC willow }\end{array}$ & 900 & willow \\
\hline [175] & 2016 & $\begin{array}{l}\text { - characterization and the effect of lignocellulosic } \\
\text { biomass value addition on gasification efficiency }\end{array}$ & 900 & sugarcane bagasse \\
\hline
\end{tabular}


Table A4. Cont.

\begin{tabular}{|c|c|c|c|c|}
\hline Ref. & Year & Application & Process Temp. $\left({ }^{\circ} \mathrm{C}\right)$ & Material \\
\hline [176] & 2016 & $\begin{array}{l}\text { - torrefied pine as a gasification fuel using a } \\
\text { bubbling fluidized bed gasifier }\end{array}$ & $790,935,1000$ & pine \\
\hline [177] & 2015 & $\begin{array}{l}\text { - the commbustion characteristics of } \\
\text { high-heating-rate chars from untreated and } \\
\text { torrefied biomass fuels }\end{array}$ & 1100 & willow, eucalyptus \\
\hline [178] & 2015 & $\begin{array}{l}\text { - characterizes the oxidation properties biomass } \\
\text { char and compare with that of raw biomass char }\end{array}$ & 900,1200 & palm kernel shell \\
\hline [179] & 2015 & $\begin{array}{l}\text { - design, optimization and energetic efficiency of } \\
\text { producing hydrogen-rich gas from biomass steam } \\
\text { gasification }\end{array}$ & 700 & oil palm \\
\hline [180] & 2014 & - gasification of torrefied wood: a kinetic study & 750 & birch, spruce \\
\hline [181] & 2014 & $\begin{array}{l}\text { - lab-scale co-firing of virgin and torrefied bamboo } \\
\text { as a fuel substitute in coal fired power plants }\end{array}$ & $1400-1600$ & $\begin{array}{l}\text { bamboo species guadua } \\
\text { angustifolia kunth, willow }\end{array}$ \\
\hline [182] & 2014 & $\begin{array}{l}\text { - gasification of torrefied Miscanthus } x \text { giganteus in } \\
\text { an air-blown bubbling fluidized bed gasifier }\end{array}$ & $600,700,750,800,850$ & miscanthus $\mathrm{x}$ giganteus \\
\hline [183] & 2014 & $\begin{array}{l}\text { - high-temperature rapid devolatilization of } \\
\text { biomasses with varying degrees of torrefaction }\end{array}$ & $500,700,900,1200$ & palm kernel shell \\
\hline [184] & 2013 & $\begin{array}{l}\text { - flame characteristics of pulverized } \\
\text { torrefied-biomass combusted with } \\
\text { high-temperature air }\end{array}$ & 1150 & palm kernel shells \\
\hline
\end{tabular}

Table A5. Other issues regarding the use of torrefied biomass—-detailed thematic analysis.

\begin{tabular}{|c|c|c|}
\hline Ref. & Year & Application \\
\hline [185] & 2019 & - Boosting carbon efficiency of the biomass to liquid process with hydrogen from power \\
\hline [186] & 2019 & - Influence of structural modification on VOC emission kinetics from stored carbonized refuse-derived fuel \\
\hline [187] & 2019 & - Process simulation of an integrated biomass torrefaction and pelletization (iBTP) \\
\hline [188] & 2019 & - Evaluating integration of biomass gasification process with solid oxide fuel cell and torrefaction process \\
\hline [189] & 2018 & $\begin{array}{l}\text { - Improving carbon efficiency and profitability of the biomass to liquid process with hydrogen from } \\
\text { renewable power }\end{array}$ \\
\hline [190] & 2018 & $\begin{array}{l}\text { - Integrated systems analysis of electricity, heat, road transport, aviation, and chemicals: a case study for the } \\
\text { Netherlands }\end{array}$ \\
\hline [191] & 2018 & $\begin{array}{l}\text { - International vs. domestic bioenergy supply chains for co-firing plants: The role of pre-treatment } \\
\text { technologies }\end{array}$ \\
\hline [192] & 2018 & $\begin{array}{l}\text { - Use of biomass in integrated steelmaking-Status quo, future needs and comparison to other low- } \mathrm{CO}_{2} \text { steel } \\
\text { production technologies }\end{array}$ \\
\hline [193] & 2018 & $\begin{array}{l}\text { - climate impact and energy efficiency of internationally traded non-torrefied and torrefied wood pellets } \\
\text { from logging residues }\end{array}$ \\
\hline [194] & 2018 & - Coupling of an acoustic emissions system to a laboratory torrefaction reactor \\
\hline [195] & 2017 & $\begin{array}{l}\text { - Technical assessment of the Biomass Integrated Gasification/Gas Turbine Combined Cycle incorporation in } \\
\text { the sugarcane industry }\end{array}$ \\
\hline [196] & 2017 & $\begin{array}{l}\text { - An LCA-based evaluation of biomass to transportation fuel production and utilization pathways in a large } \\
\text { port's context }\end{array}$ \\
\hline [197] & 2017 & $\begin{array}{l}\text { - The role of bioenergy and biochemicals in } \mathrm{CO}_{2} \text { mitigation through the energy system-a scenario analysis } \\
\text { for the Netherlands }\end{array}$ \\
\hline [198] & 2017 & $\begin{array}{l}\text { - a whole-systems analysis of the value chain associated with cultivation, harvesting, transport and } \\
\text { conversion in dedicated biomass power stations }\end{array}$ \\
\hline [199] & 2017 & - Economic impact of combined torrefaction and pelletization processes on forestry biomass supply \\
\hline [200] & 2017 & - thermoliquefaction of palm oil fiber using supercritical ethanol. \\
\hline [201] & 2017 & - The climate contribution of biomass co-combustion in a coal-fired power plant \\
\hline [202] & 2017 & $\begin{array}{l}\text { - the influence of pre-treatment of biomass on products distribution and characteristics of torrefaction } \\
\text { products }\end{array}$ \\
\hline [203] & 2016 & - Influence of mill type on densified biomass comminution. \\
\hline [204] & 2016 & $\begin{array}{l}\text { - Techno-economic and carbon emissions analysis of biomass torrefaction downstream in international } \\
\text { bioenergy supply chains for co-firing }\end{array}$ \\
\hline [205] & 2016 & $\begin{array}{l}\text { - An energy analysis comparing biomass torrefaction in depots to wind with natural gas combustion for } \\
\text { electricity generation }\end{array}$ \\
\hline
\end{tabular}


Table A5. Cont.

\begin{tabular}{|c|c|c|}
\hline Ref. & Year & Application \\
\hline [206] & 2016 & - Processing and sorting forest residues: Cost, productivity and managerial impacts \\
\hline [207] & 2016 & $\begin{array}{l}\text { - Fast hydrothermal liquefaction for production of chemicals and biofuels from wet biomass-The need to } \\
\text { develop a plug-flow reactor }\end{array}$ \\
\hline [208] & 2016 & $\begin{array}{l}\text { - Technical improvements and economic-environmental assessment along the overall torrefaction supply } \\
\text { chain through the SECTOR project }\end{array}$ \\
\hline [209] & 2016 & - an assessment of the torrefaction of north american pine and life cycle greenhouse gase emission \\
\hline [210] & 2016 & $\begin{array}{l}\text { - Optimal production scheduling for energy efficiency improvement in biofuel feedstock preprocessing } \\
\text { considering work-in-process particle separation }\end{array}$ \\
\hline [211] & 2016 & - optimization the minimum production cost for the production of woody biofuels \\
\hline [212] & 2016 & - Prediction of high-temperature rapid combustion behaviour of woody biomass particles \\
\hline [213] & 2016 & - Environmental and Energy Performance of the Biomass to Synthetic Natural Gas Supply Chain \\
\hline [214] & 2016 & - Modeling of biofuel pellets torrefaction in a realistic geometry \\
\hline [215] & 2015 & - regionalized techno-economic assessment and policy analysis for biomass molded fuel in China \\
\hline [216] & 2015 & $\begin{array}{l}\text { - Investigation into the applicability of Bond Work Index (BWI) and Hardgrove Grindability Index (HGI) } \\
\text { tests for several biomasses compared to Colombian La Loma coal }\end{array}$ \\
\hline [217] & 2015 & $\begin{array}{l}\text { - Explosion characteristics of pulverised torrefied and raw Norway spruce (Picea abies) and Southern pine } \\
\text { (Pinus palustris) in comparison to bituminous coal }\end{array}$ \\
\hline [218] & 2015 & $\begin{array}{l}\text { - high moisture corn stover pelleting in a flat die pellet mill fitted-physical properties and specific energy } \\
\text { consumption }\end{array}$ \\
\hline [219] & 2015 & - comparative cradle-to-gate life cycle assessment of wood pellet production with torrefaction \\
\hline [220] & 2011 & $\begin{array}{l}\text { - to achieve a first understanding of the possibility to combine torrefaction and hydrolysis for lignocellulosic } \\
\text { bioethanol processes, and to evaluate it in terms of sugar and ethanol yields }\end{array}$ \\
\hline
\end{tabular}

\section{References}

1. Ioannou, K.; Tsantopoulos, G.; Arabatzis, G.; Andreopoulou, Z.; Zafeiriou, E. A spatial decision support system framework for the evaluation of biomass energy production locations: Case study in the regional unit of drama, Greece. Sustainability 2018, 10, 531. [CrossRef]

2. Brunerová, A.; Roubík, H.; Brožek, M. Bamboo Fiber and Sugarcane Skin as a Bio-Briquette Fuel. Energies 2018, 11, 2186. [CrossRef]

3. Kozina, T.; Ovcharuk, O.; Trach, I.; Levytska, V.; Ovcharuk, O.; Hutsol, T.; Mudryk, K.; Jewiarz, M.; Wrobel, M.; Dziedzic, K. Spread Mustard and Prospects for Biofuels. In Renewable Energy Sources: Engineering, Technology, Innovation; Mudryk, K., Werle, S., Eds.; Springer: Cham, Switzerland, 2018; pp. 791-799.

4. Santos-Clotas, E.; Cabrera-Codony, A.; Castillo, A.; Martín, M.J.; Poch, M.; Monclús, H. Environmental decision support system for biogas upgrading to feasible fuel. Energies 2019, 12, 1546. [CrossRef]

5. Mudryk, K.; Wróbel, M.; Jewiarz, M.; Pelczar, G.; Dyjakon, A. Innovative Production Technology of High Quality Pellets for Power Plants. In Renewable Energy Sources: Engineering, Technology, Innovation; Mudryk, K., Werle, S., Eds.; Springer: Cham, Switzerland, 2018; pp. 701-712.

6. Wójcik, A.; Krupa, K.; Łapczyńska-Kondon, B.; Francik, S.; Kwaśniewski, D. The Dynamic Model of Willow Biomass Production. In Renewable Energy Sources: Engineering, Technology, Innovation; Mudryk, K., Werle, S., Eds.; Springer: Cham, Switzerland, 2018; pp. 631-638.

7. Gentil, L.V.; Vale, A.T. Energy balance and efficiency in wood sawdust briquettes production. Floresta 2015, 45, $281-288$.

8. Brunerová, A.; Roubík, H.; Brožek, M.; Herák, D.; Šleger, V.; Mazancová, J. Potential of tropical fruit waste biomass for production of bio-briquette fuel: Using Indonesia as an example. Energies 2017, 10, 2119. [CrossRef]

9. Adžić, M.M.; Savić, R.A. Cooling of wood briquettes. Therm. Sci. 2013, 17, 833-838. [CrossRef]

10. Chaloupková, V.; Ivanova, T.; Ekrt, O.; Kabutey, A.; Herák, D. Determination of particle size and distribution through image-based macroscopic analysis of the structure of biomass briquettes. Energies 2018, 11, 331. [CrossRef]

11. Moiceanu, G.; Paraschiv, G.; Voicu, G.; Dinca, M.; Negoita, O.; Chitoiu, M.; Tudor, P. Energy consumption at size reduction of lignocellulose biomass for bioenergy. Sustainability 2019, 11, 2477. [CrossRef]

12. Knapczyk, A.; Francik, S.; Fraczek, J.; Slipek, Z. Analysis of research trends in production of solid biofuels. In Proceedings of the Engineering for Rural Development, Latvia University of Life Sciences and Technologies, Jelgava, Latvia, 22-24 May 2019; Volume 18, pp. 1503-1509.

13. Ivanyshyn, V.; Nedilska, U.; Khomina, V.; Klymyshena, R.; Hryhoriev, V.; Ovcharuk, O.; Hutsol, T.; Mudryk, K.; Jewiarz, M.; Wróbel, M.; et al. Prospects of Growing Miscanthus as Alternative Source of Biofuel. In Renewable Energy Sources: Engineering, Technology, Innovation; Mudryk, K., Werle, S., Eds.; Springer: Cham, Switzerland, 2018; pp. 801-812.

14. Brunerová, A.; Müller, M.; Šleger, V.; Ambarita, H.; Valášek, P. Bio-Pellet Fuel from Oil Palm Empty Fruit Bunches (EFB): Using European Standards for Quality Testing. Sustainability 2018, 10, 4443. [CrossRef] 
15. Wang, T.; Zhai, Y.; Zhu, Y.; Gan, X.; Zheng, L.; Peng, C.; Wang, B.; Li, C.; Zeng, G. Evaluation of the clean characteristics and combustion behavior of hydrochar derived from food waste towards solid biofuel production. Bioresour. Technol. 2018, 266, 275-283. [CrossRef]

16. Perea-Moreno, M.-A.; Manzano-Agugliaro, F.; Hernandez-Escobedo, Q.; Perea-Moreno, A.-J. Peanut Shell for Energy: Properties and Its Potential to Respect the Environment. Sustainability 2018, 10, 3254. [CrossRef]

17. Wrobel, M.; Fraczek, J.; Francik, S.; Slipek, Z.; Krzysztof, M. Influence of degree of fragmentation on chosen quality parameters of briquette made from biomass of cup plant Silphium perfoliatum L. In Proceedings of the International Scientific Conference: Engineering for Rural Development, Jelgava, Latvia, 23-24 May 2013.

18. Mudryk, K.; Fraczek, J.; Slipek, Z.; Francik, S.; Wrobel, M. Chosen physico-mechanical properties of cutleaf coneflower (Rudbeckia laciniata L.) shoots. In Proceedings of the International Scientific Conference: Engineering for Rural Development, Jelgava, Latvia, 23-24 May 2013.

19. Gebresenbet, G.; Bosona, T.; Olsson, S.-O.; Garcia, D. Smart System for the Optimization of Logistics Performance of the Pruning Biomass Value Chain. Appl. Sci. 2018, 8, 1162. [CrossRef]

20. Zanetti, M.; Greco, R.; Costa, C.; Cavalli, R. Changes of particle size classification of wood chips according to the new standard rules for domestic use. Eur. J. Wood Wood Prod. 2018, 76, 805-807. [CrossRef]

21. Chin, K.L.; H'ng, P.S.; Maminski, M.; Go, W.Z.; Lee, C.L.; Raja-Nazrin, R.A.; Khoo, P.S.; Ashikin, S.N.; Halimatun, I. Additional additives to reduce ash related operation problems of solid biofuel from oil palm biomass upon combustion. Ind. Crops Prod. 2018, 123, 285-295. [CrossRef]

22. Musule, R.; Acuña, E.; Romero-Hermoso Osorio, L.S.; Domínguez, Z.; Bárcenas-Pazos, G.M.; Pineda-López, M.R.; Teixeira Mendonça, R.; González, M.E.; Sánchez-Velásquez, L.R. Growing up at Different Altitudes: Changes in Energy Content of the Abies religiosa Wood. BioEnergy Res. 2018, 11, 209-218. [CrossRef]

23. Vasiliki, K.; Charalampos, L.; Panagiotis, B. Utilization of wood and bark of fast-growing hardwood species in energy production. J. For. Sci. 2018, 64, 164-170. [CrossRef]

24. Vitázek, I.; Majdan, R.; Mojžiš, M. Volatile combustible release in biofuels. Agron. Res. 2018, 16, $2229-2241$.

25. Karbowniczak, A.; Hamerska, J.; Wróbel, M.; Jewiarz, M.; Nęcka, K. Evaluation of Selected Species of Woody Plants in Terms of Suitability for Energy Production. In Renewable Energy Sources: Engineering, Technology, Innovation; Mudryk, K., Werle, S., Eds.; Springer: Cham, Switzerland, 2018; pp. 735-742.

26. Niemczyk, M.; Kaliszewski, A.; Jewiarz, M.; Wróbel, M.; Mudryk, K. Productivity and biomass characteristics of selected poplar (Populus spp.) cultivars under the climatic conditions of northern Poland. Biomass Bioenergy 2018, 111, 46-51. [CrossRef]

27. Wróbel, M.; Mudryk, K.; Jewiarz, M.; Głowacki, S.; Tulej, W. Characterization of Selected Plant Species in Terms of Energetic Use; Springer: Cham, Switzerland, 2018; pp. 671-681.

28. Brunerová, A.; Brožek, M.; Šleger, V.; Nováková, A. Energy Balance of Briquette Production from Various Waste Biomass. Sci. Agric. Bohem. 2018, 49, 236-243. [CrossRef]

29. Kang, K.; Zhu, M.; Sun, G.; Qiu, L.; Guo, X.; Meda, V.; Sun, R. Codensification of Eucommia ulmoides Oliver stem with pyrolysis oil and char for solid biofuel: An optimization and characterization study. Appl. Energy 2018, 223, 347-357. [CrossRef]

30. Matúš, M.; Križan, P.; Šooš, L'.; Beniak, J. The effect of papermaking sludge as an additive to biomass pellets on the final quality of the fuel. Fuel 2018, 219, 196-204. [CrossRef]

31. Styks, J.; Wróbel, M.; Fraczzek, J.; Knapczyk, A. Effect of Compaction Pressure and Moisture Content on Quality Parameters of Perennial Biomass Pellets. Energies 2020, 13, 1859. [CrossRef]

32. Wróbel, M.; Jewiarz, M.; Mudryk, K.; Knapczyk, A. Influence of Raw Material Drying Temperature on the Scots Pine (Pinus sylvestris L.) Biomass Agglomeration Process-A Preliminary Study. Energies 2020, 13, 1809. [CrossRef]

33. Grottola, C.M.; Giudicianni, P.; Michel, J.B.; Ragucci, R. Torrefaction of Woody Waste for Use as Biofuel. Energy Fuels 2018, 32, 10266-10271.

34. Ramos-Carmona, S.; Martínez, J.D.; Pérez, J.F. Torrefaction of patula pine under air conditions: A chemical and structural characterization. Ind. Crops Prod. 2018, 118, 302-310. [CrossRef]

35. Viotto, R.S.; Maia, A.A.D.; Yamaji, F.M.; de Morais, L.C. Thermogravimetric investigation of spent shiitake substrate to solid biofuel. Can. J. Chem. Eng. 2018, 96, 845-854. [CrossRef]

36. Gultekin, S.Y.; Olgun, H.; Celiktas, M.S. Comparison of solid biofuels produced from olive pomace with two different conversion methods: Torrefaction and hydrothermal carbonization. Int. J. Eng. Technol. 2018, 7, 143. [CrossRef]

37. Garcia, D.P.; Caraschi, J.C.; Ventorim, G.; Vieira, F.H.A.; Protásio, T.D.P. Comparative Energy Properties of Torrefied Pellets in Relation to Pine and Elephant Grass Pellets. BioResources 2018, 13, 2898. [CrossRef]

38. Wróbel, M.; Hamerska, J.; Jewiarz, M.; Mudryk, K.; Niemczyk, M. Influence of Parameters of the Torrefaction Process on the Selected Parameters of Torrefied Woody Biomass; Springer: Cham, Switzerland, 2018; pp. 691-700.

39. Roy, P.; Dutta, A.; Gallant, J. Hydrothermal Carbonization of Peat Moss and Herbaceous Biomass (Miscanthus): A Potential Route for Bioenergy. Energies 2018, 11, 2794. [CrossRef]

40. Volpe, M.; Goldfarb, J.L.; Fiori, L. Hydrothermal carbonization of Opuntia ficus-indica cladodes: Role of process parameters on hydrochar properties. Bioresour. Technol. 2018, 247, 310-318. [CrossRef]

41. Mierzwa-Hersztek, M.; Gondek, K.; Klimkowicz-Pawlas, A.; Chmiel, M.J.; Dziedzic, K.; Taras, H. Assessment of soil quality after biochar application based on enzymatic activity and microbial composition. Int. Agrophys. 2019, 33, 331-336. [CrossRef] 
42. Głąb, T.; Żabiński, A.; Sadowska, U.; Gondek, K.; Kopeć, M.; Mierzwa-Hersztek, M.; Tabor, S.; Stanek-Tarkowska, J. Fertilization effects of compost produced from maize, sewage sludge and biochar on soil water retention and chemical properties. Soil Tillage Res. 2020, 197, 104493. [CrossRef]

43. Mierzwa-Hersztek, M.; Gondek, K.; Jewiarz, M.; Dziedzic, K. Assessment of energy parameters of biomass and biochars, leachability of heavy metals and phytotoxicity of their ashes. J. Mater. Cycles Waste Manag. 2019, 21, 786-800. [CrossRef]

44. Jewiarz, M.; Mudryk, K.; Wróbel, M.; Fraczek, J.; Dziedzic, K. Parameters affecting RDF-based pellet quality. Energies 2020, 13, 910. [CrossRef]

45. Łapczyńska-Kordon, B.; Krzysztofik, B.; Sobol, Z. Quality of dried cauliflower according to the methods and drying parameters. BIO Web Conf. 2018, 10, 02017. [CrossRef]

46. Francik, S.; Łapczyńska-Kordon, B.; Francik, R.; Wójcik, A. Modeling and Simulation of Biomass Drying Using Artificial Neural Networks. In Renewable Energy Sources: Engineering, Technology, Innovation; Mudryk, K., Werle, S., Eds.; Springer: Cham, Switzerland, 2018; pp. 571-581.

47. Gent, S.; Twedt, M.; Gerometta, C.; Almberg, E. Fundamental Theories of Torrefaction by Thermochemical Conversion. In Theoretical and Applied Aspects of Biomass Torrefaction; Elsevier: Amsterdam, The Netherlands, 2017; pp. 41-75.

48. Barik, D. Energy extraction from toxic waste originating from food processing industries. In Energy from Toxic Organic Waste for Heat and Power Generation; Elsevier: Tamil Nadu, India, 2018; pp. 17-42, ISBN 9780081025284.

49. Tursunov, O.; Dobrowolski, J.; Zubek, K.; Czerski, G.; Grzywacz, P.; Dubert, F.; Lapczynska-Kordon, B.; Klima, K.; Handke, B. Kinetic study of the pyrolysis and gasification of Rosa multiflora and Miscanthus giganteus biomasses via thermogravimetric analysis. Therm. Sci. 2018, 22, 3057-3071. [CrossRef]

50. Pritchard, A. Statistical Bibliography or Bibliometrics. J. Doc. 1969, 25, 348-349.

51. Badassa, B.B.; Sun, B.; Qiao, L. Sustainable Transport Infrastructure and Economic Returns: A Bibliometric and Visualization Analysis. Sustainability 2020, 12, 2033. [CrossRef]

52. Sun, S.; Jiang, Y.; Zheng, S. Research on Ecological Infrastructure from 1990 to 2018: A Bibliometric Analysis. Sustainability 2020, 12, 2304. [CrossRef]

53. Belmonte, J.L.; Segura-Robles, A.; Moreno-Guerrero, A.-J.; Parra-González, M.E. Machine Learning and Big Data in the Impact Literature. A Bibliometric Review with Scientific Mapping in Web of Science. Symmetry 2020, 12, 495. [CrossRef]

54. Knapczyk, A.; Francik, S.; Pedryc, N.; Hebda, T. Bibliometric analysis of research trends in engineering for rural development. In Proceedings of the 17th International Scientific Conference Engineering for Rural Development, Jelgava, Latvia, 23-25 May 2018.

55. Francik, S.; Ślipek, Z.; Fraczek, J.; Knapczyk, A. Present Trends in Research on Application of Artificial Neural Networks in Agricultural Engineering. Agric. Eng. 2016, 20, 15-25. [CrossRef]

56. Zyoud, S.H.; Waring, W.S.; Sweileh, W.M.; Al-Jabi, S.W. Global Research Trends in Lithium Toxicity from 1913 to 2015: A Bibliometric Analysis. Basic Clin. Pharmacol. Toxicol. 2017, 121, 67-73. [CrossRef]

57. Gizzi, F.T. Worldwide trends in research on the San Andreas Fault System. Arab. J. Geosci. 2015, 8, 10893-10909. [CrossRef]

58. Knapczyk, A.; Francik, S.; Wrobel, M.; Mudryk, K. Comparision of selected agriculture universities in Europe on basis of analysis of academic output. In Proceedings of the 17th International Scientific Conference Engineering for Rural Development, Jelgava, Latvia, 23-25 May 2018.

59. Knapczyk, A.; Francik, S.; Wróbel, M.; Jewiarz, M.; Mudryk, K. Decision support systems for scheduling tasks in biosystems engineering. E3S Web Conf. 2019, 132, 01008. [CrossRef]

60. Francik, S.; Knapczyk, A.; Wójcik, A.; Ślipek, Z. Optimisation Methods in Renewable Energy Sources Systems—Current Research Trends. In Renewable Energy Sources: Engineering, Technology, Innovation; Wróbel, M., Jewiarz, M., Szlęk, A., Eds.; Springer: Cham, Switzerland, 2020; pp. 841-852.

61. Hohn, E. Article on the theory of drying and torrefaction. Zeitschrift Des Vereines Dtsch. Ingenieure 1919, 63, 821-826.

62. Bridgeman, T.G.; Jones, J.M.; Shield, I.; Williams, P.T. Torrefaction of reed canary grass, wheat straw and willow to enhance solid fuel qualities and combustion properties. Fuel 2008, 87, 844-856. [CrossRef]

63. Phanphanich, M.; Mani, S. Impact of torrefaction on the grindability and fuel characteristics of forest biomass. Bioresour. Technol. 2011, 102, 1246-1253. [CrossRef]

64. Arias, B.; Pevida, C.; Fermoso, J.; Plaza, M.G.; Rubiera, F.; Pis, J.J. Influence of torrefaction on the grindability and reactivity of woody biomass. Fuel Process. Technol. 2008, 89, 169-175. [CrossRef]

65. van der Stelt, M.J.C.; Gerhauser, H.; Kiel, J.H.A.; Ptasinski, K.J. Biomass upgrading by torrefaction for the production of biofuels: A review. Biomass Bioenergy 2011, 35, 3748-3762. [CrossRef]

66. Chen, W.H.; Peng, J.; Bi, X.T. A state-of-the-art review of biomass torrefaction, densification and applications. Renew. Sustain. Energy Rev. 2015, 44, 847-866. [CrossRef]

67. Chen, W.H.; Lin, B.J.; Huang, M.Y.; Chang, J.S. Thermochemical conversion of microalgal biomass into biofuels: A review. Bioresour. Technol. 2015, 184, 314-327. [CrossRef]

68. Sukiran, M.A.; Abnisa, F.; Wan Daud, W.M.A.; Abu Bakar, N.; Loh, S.K. A review of torrefaction of oil palm solid wastes for biofuel production. Energy Convers. Manag. 2017, 149, 101-120. [CrossRef]

69. Agbor, E.; Zhang, X.; Kumar, A. A review of biomass co-firing in North America. Renew. Sustain. Energy Rev. 2014, 40, 930-943. [CrossRef] 
70. Dyjakon, A.; Noszczyk, T.; Smędzik, M. The Influence of Torrefaction Temperature on Hydrophobic Properties of Waste Biomass from Food Processing. Energies 2019, 12, 4609. [CrossRef]

71. Stępień, P.; Świechowski, K.; Hnat, M.; Kugler, S.; Stegenta-Dąbrowska, S.; Koziel, J.A.; Manczarski, P.; Białowiec, A. Waste to Carbon: Biocoal from Elephant Dung as New Cooking Fuel. Energies 2019, 12, 4344.

72. Chih, Y.-K.; Chen, W.-H.; Ong, H.C.; Show, P.L. Product Characteristics of Torrefied Wood Sawdust in Normal and Vacuum Environments. Energies 2019, 12, 3844. [CrossRef]

73. Kizuka, R.; Ishii, K.; Sato, M.; Fujiyama, A. Characteristics of wood pellets mixed with torrefied rice straw as a biomass fuel. Int. J. Energy Environ. Eng. 2019, 10, 357-365. [CrossRef]

74. Park, J.-H.; Jin, M.-H.; Lee, Y.-J.; Song, G.-S.; Choi, J.W.; Lee, D.-W.; Choi, Y.-C.; Park, S.-J.; Song, K.H.; Kim, J.-G. Two-in-One Fuel Synthetic Bioethanol-Lignin from Lignocellulose with Sewage Sludge and Its Air Pollutants Reduction Effects. Energies 2019, 12, 3072. [CrossRef]

75. Syguła, E.; Koziel, J.A.; Białowiec, A. Proof-of-Concept of Spent Mushrooms Compost Torrefaction-Studying the Process Kinetics and the Influence of Temperature and Duration on the Calorific Value of the Produced Biocoal. Energies 2019, $12,3060$.

76. Kanwal, S.; Munir, S.; Chaudhry, N.; Sana, H. Physicochemical characterization of Thar coal and torrefied corn cob. Energy Explor. Exploit. 2019, 37, 1286-1305. [CrossRef]

77. Yoshida, T.; Kubojima, Y.; Kamikawa, D.; Kiguchi, M.; Tanaka, K.; Miyago, M.; Masui, M.; Ohyabu, Y.; Kobayashi, A.; Igarashi, H. Production Test of Torrefied Woody Biomass Solid Fuel in an Original Small Scale Plant: (2) Effects of Automatic Temperature Control in Torrefaction and the Use of Additives in Pelletization. J. Japan Inst. Energy 2019, 98, 90-94. [CrossRef]

78. Dudek, M.; Świechowski, K.; Manczarski, P.; Koziel, J.; Białowiec, A. The Effect of Biochar Addition on the Biogas Production Kinetics from the Anaerobic Digestion of Brewers' Spent Grain. Energies 2019, 12, 1518. [CrossRef]

79. Pulka, J.; Manczarski, P.; Koziel, J.; Białowiec, A. Torrefaction of Sewage Sludge: Kinetics and Fuel Properties of Biochars. Energies 2019, 12, 565. [CrossRef]

80. Yang, Y.; Sun, M.; Zhang, M.; Zhang, K.; Wang, D.; Lei, C. A fundamental research on synchronized torrefaction and pelleting of biomass. Renew. Energy 2019, 142, 668-676. [CrossRef]

81. Stępień, P.; Serowik, M.; Koziel, J.A.; Białowiec, A. Waste to carbon: Estimating the energy demand for production of carbonized refuse-derived fuel. Sustainability 2019, 11, 5685. [CrossRef]

82. González Martínez, M.; Dupont, C.; Thiéry, S.; Meyer, X.-M.; Gourdon, C. Impact of biomass diversity on torrefaction: Study of solid conversion and volatile species formation through an innovative TGA-GC/MS apparatus. Biomass Bioenergy 2018, 119, 43-53. [CrossRef]

83. Song, X.; Yang, Y.; Zhang, M.; Zhang, K.; Wang, D. Ultrasonic pelleting of torrefied lignocellulosic biomass for bioenergy production. Renew. Energy 2018, 129, 56-62. [CrossRef]

84. Bajcar, M.; Zaguła, G.; Saletnik, B.; Tarapatskyy, M.; Puchalski, C. Relationship between Torrefaction Parameters and Physicochemical Properties of Torrefied Products Obtained from Selected Plant Biomass. Energies 2018, 11, 2919. [CrossRef]

85. Białowiec, A.; Micuda, M.; Koziel, J. Waste to Carbon: Densification of Torrefied Refuse-Derived Fuel. Energies 2018, 11, 3233. [CrossRef]

86. Hasan, M.; Haseli, Y.; Karadogan, E. Correlations to Predict Elemental Compositions and Heating Value of Torrefied Biomass. Energies 2018, 11, 2443. [CrossRef]

87. Ali, M.; Watson, I.A. Mild Pyrolysis of Manually Pressed and Liquid Nitrogen Treated De-Lipid Cake of Nannochloropsis Oculata for Bioenergy Utilisation. Energy Technol. 2018, 6, 1642-1648. [CrossRef]

88. Yoshida, T.; Kubojima, Y.; Kamikawa, D.; Kiguchi, M.; Tanaka, K.; Miyago, M.; Masui, M.; Ohyabu, Y.; Kobayashi, A.; Igarashi, H. Production Test of Torrefied Woody Biomass Solid Fuel in an Original Small-scale Plant. J. Jpn. Inst. Energy 2018, 97, 231-235. [CrossRef]

89. Chen, D.; Gao, A.; Cen, K.; Zhang, J.; Cao, X.; Ma, Z. Investigation of biomass torrefaction based on three major components: Hemicellulose, cellulose, and lignin. Energy Convers. Manag. 2018, 169, 228-237. [CrossRef]

90. Xu, Z.; Zinchik, S.; Kolapkar, S.S.; Bar-Ziv, E.; Hansen, T.; Conn, D.; McDonald, A.G. Properties of Torrefied U.S. Waste Blends. Front. Energy Res. 2018, 6. [CrossRef]

91. Poudel, J.; Karki, S.; Oh, S. Valorization of Waste Wood as a Solid Fuel by Torrefaction. Energies 2018, 11, 1641. [CrossRef]

92. Gaitán-Álvarez, J.; Moya, R.; Puente-Urbina, A.; Rodriguez-Zúñiga, A. Thermogravimetric, Devolatilization Rate, and Differential Scanning Calorimetry Analyses of Biomass of Tropical Plantation Species of Costa Rica Torrefied at Different Temperatures and Times. Energies 2018, 11, 696. [CrossRef]

93. Tic, W.; Guziałowska-Tic, J.; Pawlak-Kruczek, H.; Woźnikowski, E.; Zadorożny, A.; Niedźwiecki, Ł.; Wnukowski, M.; Krochmalny, K.; Czerep, M.; Ostrycharczyk, M.; et al. Novel Concept of an Installation for Sustainable Thermal Utilization of Sewage Sludge. Energies 2018, 11, 748. [CrossRef]

94. Banta, M.T.A.; De Leon, R.L. Parametric study of rice husk torrefaction for the development of sustainable solid fuel. Int. J. Smart Grid Clean Energy 2018, 7, 207-217. [CrossRef]

95. Mamvura, T.A.; Pahla, G.; Muzenda, E. Torrefaction of waste biomass for application in energy production in South Africa. S. Afr. J. Chem. Eng. 2018, 25, 1-12. [CrossRef]

96. Tanchuling, J.; De Leon, R. Solid fuel characterization of torrefied coconut shells in an oxidative environment. Int. J. Smart Grid Clean Energy 2018, 7, 145-151. [CrossRef] 
97. Palanca, A.G.; de Leon, R.L.; Jose, W.I. Torrefied cogon grass: Effects of torrefaction on fuel properties of solid and condensate products. Int. J. Smart Grid Clean Energy 2018, 7, 1-12. [CrossRef]

98. Barta-Rajnai, E.; Wang, L.; Sebestyén, Z.; Barta, Z.; Khalil, R.; Skreiberg, Ø.; Grønli, M.; Jakab, E.; Czégény, Z. Comparative study on the thermal behavior of untreated and various torrefied bark, stem wood, and stump of Norway spruce. Appl. Energy 2017, 204, 1043-1054. [CrossRef]

99. Gaitán-Alvarez, J.; Moya, R.; Puente-Urbina, A.; Rodriguez-Zuñiga, A. Physical and Compression Properties of Pellets Manufactured with the Biomass of Five Woody Tropical Species of Costa Rica Torrefied at Different Temperatures and Times. Energies 2017, 10, 1205. [CrossRef]

100. Yoshida, T.; Kubojima, Y.; Kamikawa, D.; Inoue, M.; Kiguchi, M.; Tanaka, K.; Murata, Y.; Masui, M.; Ohyabu, Y.; Tsuru, T.; et al. Preliminary Production Test of Torrefied Woody Biomass Fuel in a Small Scale Plant. J. Jpn. Inst. Energy 2017, 96, 310-313. [CrossRef]

101. Huang, M.; Chang, C.-C.; Yuan, M.-H.; Chang, C.-Y.; Wu, C.-H.; Shie, J.-L.; Chen, Y.-H.; Chen, Y.-H.; Ho, C.; Chang, W.-R.; et al. Production of Torrefied Solid Bio-Fuel from Pulp Industry Waste. Energies 2017, 10, 910. [CrossRef]

102. Yue, Y.; Singh, H.; Singh, B.; Mani, S. Torrefaction of sorghum biomass to improve fuel properties. Bioresour. Technol. 2017, 232, 372-379. [CrossRef]

103. Pahla, G.; Mamvura, T.A.; Ntuli, F.; Muzenda, E. Energy densification of animal waste lignocellulose biomass and raw biomass. S. Afr. J. Chem. Eng. 2017, 24, 168-175. [CrossRef]

104. Pestaño, L.D.B.; Jose, W.I. Production of Solid Fuel by Torrefaction Using Coconut Leaves As Renewable Biomass. Int. J. Renew. Energy Dev. 2016, 5, 187. [CrossRef]

105. Khalsa, J.; Leistner, D.; Weller, N.; Darvell, L.; Dooley, B. Torrefied Biomass Pellets-Comparing Grindability in Different Laboratory Mills. Energies 2016, 9, 794. [CrossRef]

106. Barta-Rajnai, E.; Jakab, E.; Sebestyén, Z.; May, Z.; Barta, Z.; Wang, L.; Skreiberg, Ø.; Grønli, M.; Bozi, J.; Czégény, Z. Comprehensive Compositional Study of Torrefied Wood and Herbaceous Materials by Chemical Analysis and Thermoanalytical Methods. Energy Fuels 2016, 30, 8019-8030. [CrossRef]

107. Kim, P.; Lloyd, J.; Kim, J.-W.; Abdoulmoumine, N.; Labbé, N. Recovery of creosote from used railroad ties by thermal desorption. Energy 2016, 111, 226-236. [CrossRef]

108. Nanou, P.; Carbo, M.C.; Kiel, J.H.A. Detailed mapping of the mass and energy balance of a continuous biomass torrefaction plant. Biomass Bioenergy 2016, 89, 67-77. [CrossRef]

109. Madanayake, B.N.; Gan, S.; Eastwick, C.; Ng, H.K. Thermochemical and structural changes in Jatropha curcas seed cake during torrefaction for its use as coal co-firing feedstock. Energy 2016, 100, 262-272. [CrossRef]

110. Normark, M.; Pommer, L.; Gräsvik, J.; Hedenström, M.; Gorzsás, A.; Winestrand, S.; Jönsson, L.J. Biochemical Conversion of Torrefied Norway Spruce After Pretreatment with Acid or Ionic Liquid. BioEnergy Res. 2016, 9, 355-368. [CrossRef]

111. Lê Thành, K.; Commandré, J.-M.; Valette, J.; Volle, G.; Meyer, M. Detailed identification and quantification of the condensable species released during torrefaction of lignocellulosic biomasses. Fuel Process. Technol. 2015, 139, 226-235. [CrossRef]

112. Gao, Q.; Haglund, P.; Pommer, L.; Jansson, S. Evaluation of solvent for pressurized liquid extraction of PCDD, PCDF, PCN, PCBz, PCPh and PAH in torrefied woody biomass. Fuel 2015, 154, 52-58. [CrossRef]

113. Gucho, E.; Shahzad, K.; Bramer, E.; Akhtar, N.; Brem, G. Experimental Study on Dry Torrefaction of Beech Wood and Miscanthus. Energies 2015, 8, 3903-3923. [CrossRef]

114. Fagernäs, L.; Kuoppala, E.; Arpiainen, V. Composition, Utilization and Economic Assessment of Torrefaction Condensates. Energy Fuels 2015, 29, 3134-3142. [CrossRef]

115. Tumuluru, J.; Lim, C.; Bi, X.; Kuang, X.; Melin, S.; Yazdanpanah, F.; Sokhansanj, S. Analysis on Storage Off-Gas Emissions from Woody, Herbaceous, and Torrefied Biomass. Energies 2015, 8, 1745-1759. [CrossRef]

116. Acharya, B.; Pradhan, R.R.; Dutta, A. Qualitative and kinetic analysis of torrefaction of lignocellulosic biomass using DSC-TGAFTIR. AIMS Energy 2015, 3, 760-773. [CrossRef]

117. Tumuluru, J.S. Comparison of Chemical Composition and Energy Property of Torrefied Switchgrass and Corn Stover. Front. Energy Res. 2015, 3. [CrossRef]

118. Poudel, J.; Oh, S. Effect of Torrefaction on the Properties of Corn Stalk to Enhance Solid Fuel Qualities. Energies 2014, 7, 5586-5600. [CrossRef]

119. Lasode, O.A.; Balogun, A.O.; McDonald, A.G. Torrefaction of some Nigerian lignocellulosic resources and decomposition kinetics. J. Anal. Appl. Pyrolysis 2014, 109, 47-55. [CrossRef]

120. Li, J.; Zhang, X.; Pawlak-Kruczek, H.; Yang, W.; Kruczek, P.; Blasiak, W. Process simulation of co-firing torrefied biomass in a 220MWe coal-fired power plant. Energy Convers. Manag. 2014, 84, 503-511. [CrossRef]

121. Kaminaka, K.; Matsumura, Y.; Noaman Omar, W.; Uemura, Y. Process Evaluation for Torrefaction of Empty Fruit Bunch in Malaysia. J. Jpn. Pet. Inst. 2014, 57, 88-93. [CrossRef]

122. Lu, J.-J.; Chen, W.-H. Product Yields and Characteristics of Corncob Waste under Various Torrefaction Atmospheres. Energies 2013, 7, 13-27. [CrossRef]

123. Saleh, S.B.; Hansen, B.B.; Jensen, P.A.; Dam-Johansen, K. Efficient Fuel Pretreatment: Simultaneous Torrefaction and Grinding of Biomass. Energy Fuels 2013, 27, 7531-7540. [CrossRef] 
124. Saleh, S.B.; Hansen, B.B.; Jensen, P.A.; Dam-Johansen, K. Influence of Biomass Chemical Properties on Torrefaction Characteristics. Energy Fuels 2013, 27, 7541-7548. [CrossRef]

125. Tapasvi, D.; Khalil, R.; Várhegyi, G.; Tran, K.-Q.; Grønli, M.; Skreiberg, Ø. Thermal Decomposition Kinetics of Woods with an Emphasis on Torrefaction. Energy Fuels 2013, 27, 6134-6145. [CrossRef]

126. Gronnow, M.J.; Budarin, V.L.; Mašek, O.; Crombie, K.N.; Brownsort, P.A.; Shuttleworth, P.S.; Hurst, P.R.; Clark, J.H. Torrefaction/biochar production by microwave and conventional slow pyrolysis-Comparison of energy properties. GCB Bioenergy 2013, 5, 144-152. [CrossRef]

127. Tapasvi, D.; Khalil, R.; Várhegyi, G.; Skreiberg, Ø.; Tran, K.-Q.; Grønli, M. Kinetic Behavior of Torrefied Biomass in an Oxidative Environment. Energy Fuels 2013, 27, 1050-1060. [CrossRef]

128. Tumuluru, J.; Boardman, R.; Wright, C.; Hess, J. Some Chemical Compositional Changes in Miscanthus and White Oak Sawdust Samples during Torrefaction. Energies 2012, 5, 3928-3947. [CrossRef]

129. Rousset, P.; Macedo, L.; Commandré, J.-M.; Moreira, A. Biomass torrefaction under different oxygen concentrations and its effect on the composition of the solid by-product. J. Anal. Appl. Pyrolysis 2012, 96, 86-91. [CrossRef]

130. Medic, D.; Darr, M.; Shah, A.; Rahn, S. The Effects of Particle Size, Different Corn Stover Components, and Gas Residence Time on Torrefaction of Corn Stover. Energies 2012, 5, 1199-1214. [CrossRef]

131. Medic, D.; Darr, M.; Shah, A.; Rahn, S. Effect of Torrefaction on Water Vapor Adsorption Properties and Resistance to Microbial Degradation of Corn Stover. Energy Fuels 2012, 26, 2386-2393. [CrossRef]

132. Tu, R.; Sun, Y.; Wu, Y.; Fan, X.; Wang, J.; Cheng, S.; Jia, Z.; Jiang, E.; Xu, X. Improvement of corn stover fuel properties via hydrothermal carbonization combined with surfactant. Biotechnol. Biofuels 2019, 12, 249. [CrossRef] [PubMed]

133. Bhatt, D.; Shrestha, A.; Dahal, R.; Acharya, B.; Basu, P.; MacEwen, R. Hydrothermal Carbonization of Biosolids from Waste Water Treatment Plant. Energies 2018, 11, 2286. [CrossRef]

134. Zhang, B.; Heidari, M.; Regmi, B.; Salaudeen, S.; Arku, P.; Thimmannagari, M.; Dutta, A. Hydrothermal Carbonization of Fruit Wastes: A Promising Technique for Generating Hydrochar. Energies 2018, 11, 2022. [CrossRef]

135. Stirling, R.J.; Snape, C.E.; Meredith, W. The impact of hydrothermal carbonisation on the char reactivity of biomass. Fuel Process. Technol. 2018, 177, 152-158. [CrossRef]

136. Kruse, A.; Zevaco, T. Properties of Hydrochar as Function of Feedstock, Reaction Conditions and Post-Treatment. Energies 2018, 11, 674. [CrossRef]

137. Castro-Díaz, M.; Uguna, C.N.; Florentino, L.; Díaz-Faes, E.; Stevens, L.A.; Barriocanal, C.; Snape, C.E. Evaluation of hydrochars from lignin hydrous pyrolysis to produce biocokes after carbonization. J. Anal. Appl. Pyrolysis 2017, 124, 742-751. [CrossRef]

138. Hoekman, S.K.; Broch, A.; Felix, L.; Farthing, W. Hydrothermal carbonization (HTC) of loblolly pine using a continuous, reactive twin-screw extruder. Energy Convers. Manag. 2017, 134, 247-259. [CrossRef]

139. Lucian, M.; Fiori, L. Hydrothermal Carbonization of Waste Biomass: Process Design, Modeling, Energy Efficiency and Cost Analysis. Energies 2017, 10, 211. [CrossRef]

140. Bach, Q.-V.; Tran, K.-Q.; Skreiberg, Ø.; Khalil, R.A.; Phan, A.N. Effects of wet torrefaction on reactivity and kinetics of wood under air combustion conditions. Fuel 2014, 137, 375-383. [CrossRef]

141. Lee, Y.-E.; Shin, D.-C.; Jeong, Y.; Kim, I.-T.; Yoo, Y.-S. Effects of Pyrolysis Temperature and Retention Time on Fuel Characteristics of Food Waste Feedstuff and Compost for Co-Firing in Coal Power Plants. Energies 2019, 12, 4538. [CrossRef]

142. Westerhof, R.; Oudenhoven, S.; Hu, X.; van, S.; Kersten, S. Combined organic acid leaching and torrefaction as pine wood pretreatment before fast pyrolysis. Therm. Sci. 2019, 23, 1403-1411. [CrossRef]

143. Saito, Y.; Sakuragi, K.; Shoji, T.; Otaka, M. Expedient Prediction of the Fuel Properties of Carbonized Woody Biomass Based on Hue Angle. Energies 2018, 11, 1191. [CrossRef]

144. Atienza-Martínez, M.; Ábrego, J.; Mastral, J.F.; Ceamanos, J.; Gea, G. Energy and exergy analyses of sewage sludge thermochemical treatment. Energy 2018, 144, 723-735. [CrossRef]

145. Wang, P.; Howard, B.H. Impact of Thermal Pretreatment Temperatures on Woody Biomass Chemical Composition, Physical Properties and Microstructure. Energies 2017, 11, 25. [CrossRef]

146. Louwes, A.C.; Basile, L.; Yukananto, R.; Bhagwandas, J.C.; Bramer, E.A.; Brem, G. Torrefied biomass as feed for fast pyrolysis: An experimental study and chain analysis. Biomass Bioenergy 2017, 105, 116-126. [CrossRef]

147. Waters, C.L.; Janupala, R.R.; Mallinson, R.G.; Lobban, L.L. Staged thermal fractionation for segregation of lignin and cellulose pyrolysis products: An experimental study of residence time and temperature effects. J. Anal. Appl. Pyrolysis 2017, 126, 380-389. [CrossRef]

148. Barta-Rajnai, E.; Várhegyi, G.; Wang, L.; Skreiberg, Ø.; Grønli, M.; Czégény, Z. Thermal Decomposition Kinetics of Wood and Bark and Their Torrefied Products. Energy Fuels 2017, 31, 4024-4034. [CrossRef]

149. Yang, Y.; Brammer, J.G.; Wright, D.G.; Scott, J.A.; Serrano, C.; Bridgwater, A.V. Combined heat and power from the intermediate pyrolysis of biomass materials: Performance, economics and environmental impact. Appl. Energy 2017, 191, 639-652. [CrossRef]

150. Volpe, R.; Menendez, J.M.B.; Reina, T.R.; Messineo, A.; Millan, M. Evolution of chars during slow pyrolysis of citrus waste. Fuel Process. Technol. 2017, 158, 255-263. [CrossRef]

151. Chen, Y.; Cao, W.; Atreya, A. An experimental study to investigate the effect of torrefaction temperature and time on pyrolysis of centimeter-scale pine wood particles. Fuel Process. Technol. 2016, 153, 74-80. [CrossRef] 
152. Van Poucke, R.; Nachenius, R.W.; Agbo, K.E.; Hensgen, F.; Bühle, L.; Wachendorf, M.; Ok, Y.S.; Tack, F.M.G.; Prins, W.; Ronsse, F.; et al. Mild hydrothermal conditioning prior to torrefaction and slow pyrolysis of low-value biomass. Bioresour. Technol. 2016, 217, 104-112. [CrossRef]

153. Kim, P.; Lloyd, J.; Kim, J.-W.; Labbé, N. Thermal desorption of creosote remaining in used railroad ties: Investigation by TGA (thermogravimetric analysis) and Py-GC/MS (pyrolysis-gas chromatography/mass spectrometry). Energy 2016, 96, 294-302. [CrossRef]

154. Mahadevan, R.; Adhikari, S.; Shakya, R.; Wang, K.; Dayton, D.C.; Li, M.; Pu, Y.; Ragauskas, A.J. Effect of torrefaction temperature on lignin macromolecule and product distribution from HZSM-5 catalytic pyrolysis. J. Anal. Appl. Pyrolysis 2016, 122, 95-105. [CrossRef]

155. Klinger, J.; Bar-Ziv, E.; Shonnard, D. Unified kinetic model for torrefaction-pyrolysis. Fuel Process. Technol. 2015, 138, 175-183. [CrossRef]

156. Wei, L.; Liang, S.; Guho, N.M.; Hanson, A.J.; Smith, M.W.; Garcia-Perez, M.; McDonald, A.G. Production and characterization of bio-oil and biochar from the pyrolysis of residual bacterial biomass from a polyhydroxyalkanoate production process. J. Anal. Appl. Pyrolysis 2015, 115, 268-278. [CrossRef]

157. Sadaka, S.; Sharara, M.; Ashworth, A.; Keyser, P.; Allen, F.; Wright, A. Characterization of Biochar from Switchgrass Carbonization. Energies 2014, 7, 548-567. [CrossRef]

158. Anderson, N.; Jones, J.; Page-Dumroese, D.; McCollum, D.; Baker, S.; Loeffler, D.; Chung, W. A Comparison of Producer Gas, Biochar, and Activated Carbon from Two Distributed Scale Thermochemical Conversion Systems Used to Process Forest Biomass. Energies 2013, 6, 164-183. [CrossRef]

159. Shen, D.K.; Gu, S.; Luo, K.H.; Bridgwater, A.V.; Fang, M.X. Kinetic study on thermal decomposition of woods in oxidative environment. Fuel 2009, 88, 1024-1030. [CrossRef]

160. Abelha, P.; Mourão Vilela, C.; Nanou, P.; Carbo, M.; Janssen, A.; Leiser, S. Combustion improvements of upgraded biomass by washing and torrefaction. Fuel 2019, 253, 1018-1033. [CrossRef]

161. Iáñez-Rodríguez, I.; Martín-Lara, M.Á.; Blázquez, G.; Osegueda, Ó.; Calero, M. Thermal analysis of olive tree pruning and the by-products obtained by its gasification and pyrolysis: The effect of some heavy metals on their devolatilization behavior. $J$. Energy Chem. 2019, 32, 105-117. [CrossRef]

162. Szwaja, S.; Poskart, A.; Zajemska, M.; Szwaja, M. Theoretical and Experimental Analysis on Co-Gasification of Sewage Sludge with Energetic Crops. Energies 2019, 12, 1750. [CrossRef]

163. Pawlak-Kruczek, H.; Wnukowski, M.; Niedzwiecki, L.; Czerep, M.; Kowal, M.; Krochmalny, K.; Zgóra, J.; Ostrycharczyk, M.; Baranowski, M.; Tic, W.J.; et al. Torrefaction as a Valorization Method Used Prior to the Gasification of Sewage Sludge. Energies 2019, 12, 175. [CrossRef]

164. Ahmad, R.; Ishak, M.A.M.; Ismail, K.; Kasim, N.N. Influence of microwave pre-treated Palm Kernel Shell and Mukah Balingian coal on co-gasification. J. Mech. Eng. Sci. 2019, 13, 5791-5803. [CrossRef]

165. Li, T.; Niu, Y.; Wang, L.; Shaddix, C.; Løvås, T. High temperature gasification of high heating-rate chars using a flat-flame reactor. Appl. Energy 2018, 227, 100-107. [CrossRef]

166. Xue, J.; Chellappa, T.; Ceylan, S.; Goldfarb, J.L. Enhancing biomass + coal Co-firing scenarios via biomass torrefaction and carbonization: Case study of avocado pit biomass and Illinois No. 6 coal. Renew. Energy 2018, 122, 152-162. [CrossRef]

167. Howell, A.; Beagle, E.; Belmont, E. Torrefaction of Healthy and Beetle Kill Pine and Co-Combustion with Sub-Bituminous Coal. J. Energy Resour. Technol. 2018, 140, 042002. [CrossRef]

168. Kajina, W.; Rousset, P.; Chen, W.-H.; Sornpitak, T.; Commandré, J.M. Coupled effect of torrefaction and blending on chemical and energy properties for combustion of major open burned agriculture residues in Thailand. Renew. Energy 2018, 118, 113-121. [CrossRef]

169. Beagle, E.; Wang, Y.; Bell, D.; Belmont, E. Co-gasification of pine and oak biochar with sub-bituminous coal in carbon dioxide. Bioresour. Technol. 2018, 251, 31-39. [CrossRef]

170. Tsalidis, G.A.; Di Marcello, M.; Spinelli, G.; de Jong, W.; Kiel, J.H.A. The effect of torrefaction on the process performance of oxygen-steam blown CFB gasification of hardwood and softwood. Biomass Bioenergy 2017, 106, 155-165. [CrossRef]

171. Di Marcello, M.; Tsalidis, G.A.; Spinelli, G.; de Jong, W.; Kiel, J.H.A. Pilot scale steam-oxygen CFB gasification of commercial torrefied wood pellets. The effect of torrefaction on the gasification performance. Biomass Bioenergy 2017, 105, 411-420. [CrossRef]

172. Jones, J.M.; Ross, A.B.; Mitchell, E.J.S.; Lea-Langton, A.R.; Williams, A.; Bartle, K.D. Organic carbon emissions from the co-firing of coal and wood in a fixed bed combustor. Fuel 2017, 195, 226-231. [CrossRef]

173. González-Vázquez, M.; García, R.; Pevida, C.; Rubiera, F. Optimization of a Bubbling Fluidized Bed Plant for Low-Temperature Gasification of Biomass. Energies 2017, 10, 306. [CrossRef]

174. Woytiuk, K.; Campbell, W.; Gerspacher, R.; Evitts, R.W.; Phoenix, A. The effect of torrefaction on syngas quality metrics from fluidized bed gasification of SRC willow. Renew. Energy 2017, 101, 409-416. [CrossRef]

175. Anukam, A.I.; Mamphweli, S.N.; Reddy, P.; Okoh, O.O. Characterization and the effect of lignocellulosic biomass value addition on gasification efficiency. Energy Explor. Exploit. 2016, 34, 865-880. [CrossRef]

176. Kulkarni, A.; Baker, R.; Abdoulmomine, N.; Adhikari, S.; Bhavnani, S. Experimental study of torrefied pine as a gasification fuel using a bubbling fluidized bed gasifier. Renew. Energy 2016, 93, 460-468. [CrossRef] 
177. McNamee, P.; Darvell, L.I.; Jones, J.M.; Williams, A. The combustion characteristics of high-heating-rate chars from untreated and torrefied biomass fuels. Biomass Bioenergy 2015, 82, 63-72. [CrossRef]

178. Li, J.; Bonvicini, G.; Biagini, E.; Yang, W.; Tognotti, L. Characterization of high-temperature rapid char oxidation of raw and torrefied biomass fuels. Fuel 2015, 143, 492-498. [CrossRef]

179. Kuo, P.-C.; Wu, W. Design, Optimization and Energetic Efficiency of Producing Hydrogen-Rich Gas from Biomass Steam Gasification. Energies 2014, 8, 94-110. [CrossRef]

180. Wang, L.; Várhegyi, G.; Skreiberg, Ø. CO Gasification of Torrefied Wood: A Kinetic Study. Energy Fuels 2014, 28, 7582-7590. [CrossRef]

181. Fryda, L.; Daza, C.; Pels, J.; Janssen, A.; Zwart, R. Lab-scale co-firing of virgin and torrefied bamboo species Guadua angustifolia Kunth as a fuel substitute in coal fired power plants. Biomass Bioenergy 2014, 65, 28-41. [CrossRef]

182. Xue, G.; Kwapinska, M.; Horvat, A.; Kwapinski, W.; Rabou, L.P.L.M.; Dooley, S.; Czajka, K.M.; Leahy, J.J. Gasification of torrefied Miscanthus $\times$ giganteus in an air-blown bubbling fluidized bed gasifier. Bioresour. Technol. 2014, 159, 397-403. [CrossRef]

183. Li, J.; Bonvicini, G.; Tognotti, L.; Yang, W.; Blasiak, W. High-temperature rapid devolatilization of biomasses with varying degrees of torrefaction. Fuel 2014, 122, 261-269. [CrossRef]

184. Li, J.; Biagini, E.; Yang, W.; Tognotti, L.; Blasiak, W. Flame characteristics of pulverized torrefied-biomass combusted with high-temperature air. Combust. Flame 2013, 160, 2585-2594. [CrossRef]

185. Ostadi, M.; Rytter, E.; Hillestad, M. Boosting carbon efficiency of the biomass to liquid process with hydrogen from power: The effect of $\mathrm{H} 2 / \mathrm{CO}$ ratio to the Fischer-Tropsch reactors on the production and power consumption. Biomass Bioenergy 2019, 127, 105282. [CrossRef]

186. Białowiec, A.; Micuda, M.; Szumny, A.; Łyczko, J.; Koziel, J.A. Waste to carbon: Influence of structural modification on VOC emission kinetics from stored carbonized refuse-derived fuel. Sustainability 2019, 11, 935. [CrossRef]

187. Manouchehrinejad, M.; Mani, S. Process simulation of an integrated biomass torrefaction and pelletization (iBTP) plant to produce solid biofuels. Energy Convers. Manag. X 2019, 1, 100008. [CrossRef]

188. Abbasi, H.; Rahimpour, F.; Rahimpour, F.; Kasaeian, A. Evaluating integration of biomass gasification process with solid oxide fuel cell and torrefaction process. J. Therm. Eng. 2019, 5, 230-239.

189. Hillestad, M.; Ostadi, M.; Alamo Serrano, G.; Rytter, E.; Austbø, B.; Pharoah, J.G.; Burheim, O.S. Improving carbon efficiency and profitability of the biomass to liquid process with hydrogen from renewable power. Fuel 2018, 234, 1431-1451. [CrossRef]

190. Tsiropoulos, I.; Hoefnagels, R.; de Jong, S.; van den Broek, M.; Patel, M.; Faaij, A. Emerging bioeconomy sectors in energy systems modeling-Integrated systems analysis of electricity, heat, road transport, aviation, and chemicals: A case study for the Netherlands. Biofuels Bioprod. Biorefin. 2018, 12, 665-693. [CrossRef]

191. Mauro, C.; Rentizelas, A.A.; Chinese, D. International vs. domestic bioenergy supply chains for co-firing plants: The role of pre-treatment technologies. Renew. Energy 2018, 119, 712-730. [CrossRef]

192. Suopajärvi, H.; Umeki, K.; Mousa, E.; Hedayati, A.; Romar, H.; Kemppainen, A.; Wang, C.; Phounglamcheik, A.; Tuomikoski, S.; Norberg, N.; et al. Use of biomass in integrated steelmaking-Status quo, future needs and comparison to other low-CO2 steel production technologies. Appl. Energy 2018, 213, 384-407. [CrossRef]

193. Porsö, C.; Hammar, T.; Nilsson, D.; Hansson, P.-A. Time-Dependent Climate Impact and Energy Efficiency of Internationally Traded Non-torrefied and Torrefied Wood Pellets from Logging Residues. BioEnergy Res. 2018, 11, 139-151. [CrossRef]

194. Silveira, E.A.; de Morais, M.V.G.; Rousset, P.; Caldeira-Pires, A.; Pétrissans, A.; Galvão, L.G.O. Coupling of an acoustic emissions system to a laboratory torrefaction reactor. J. Anal. Appl. Pyrolysis 2018, 129, 29-36. [CrossRef]

195. Pedroso, D.T.; Machin, E.B.; Proenza Pérez, N.; Braga, L.B.; Silveira, J.L. Technical assessment of the Biomass Integrated Gasification/Gas Turbine Combined Cycle (BIG/GTCC) incorporation in the sugarcane industry. Renew. Energy 2017, 114, 464-479. [CrossRef]

196. Tsalidis, G.A.; Discha, F.E.; Korevaar, G.; Haije, W.; de Jong, W.; Kiel, J. An LCA-based evaluation of biomass to transportation fuel production and utilization pathways in a large port's context. Int. J. Energy Environ. Eng. 2017, 8, 175-187. [CrossRef]

197. Tsiropoulos, I.; Hoefnagels, R.; van den Broek, M.; Patel, M.K.; Faaij, A.P.C. The role of bioenergy and biochemicals in CO mitigation through the energy system-A scenario analysis for the Netherlands. GCB Bioenergy 2017, 9, 1489-1509. [CrossRef]

198. Fajardy, M.; Mac Dowell, N. Can BECCS deliver sustainable and resource efficient negative emissions? Energy Environ. Sci. 2017, 10, 1389-1426. [CrossRef]

199. Li, Y.; Tittmann, P.; Parker, N.; Jenkins, B. Economic impact of combined torrefaction and pelletization processes on forestry biomass supply. GCB Bioenergy 2017, 9, 681-693. [CrossRef]

200. Oliveira, A.L.P.C.; Almeida, P.S.; Campos, M.C.V.; Franceschi, E.; Dariva, C.; Borges, G.R. Thermoliquefaction of palm oil fiber (Elaeis sp.) using supercritical ethanol. Bioresour. Technol. 2017, 230, 1-7. [CrossRef] [PubMed]

201. Miedema, J.H.; Benders, R.M.J.; Moll, H.C.; Pierie, F. Renew, reduce or become more efficient? The climate contribution of biomass co-combustion in a coal-fired power plant. Appl. Energy 2017, 187, 873-885. [CrossRef]

202. Xu, X.; Jiang, E.; Lan, X. Influence of pre-treatment on torrefaction of Phyllostachys edulis. Bioresour. Technol. 2017, 239, 97-104. [CrossRef]

203. Williams, O.; Newbolt, G.; Eastwick, C.; Kingman, S.; Giddings, D.; Lormor, S.; Lester, E. Influence of mill type on densified biomass comminution. Appl. Energy 2016, 182, 219-231. [CrossRef] 
204. Rentizelas, A.A.; Li, J. Techno-economic and carbon emissions analysis of biomass torrefaction downstream in international bioenergy supply chains for co-firing. Energy 2016, 114, 129-142. [CrossRef]

205. Parkhurst, K.M.; Saffron, C.M.; Miller, R.O. An energy analysis comparing biomass torrefaction in depots to wind with natural gas combustion for electricity generation. Appl. Energy 2016, 179, 171-181. [CrossRef]

206. Kizha, A.R.; Han, H.-S. Processing and sorting forest residues: Cost, productivity and managerial impacts. Biomass Bioenergy 2016, 93, 97-106. [CrossRef]

207. Tran, K.-Q. Fast hydrothermal liquefaction for production of chemicals and biofuels from wet biomass-The need to develop a plug-flow reactor. Bioresour. Technol. 2016, 213, 327-332. [CrossRef] [PubMed]

208. Thrän, D.; Witt, J.; Schaubach, K.; Kiel, J.; Carbo, M.; Maier, J.; Ndibe, C.; Koppejan, J.; Alakangas, E.; Majer, S.; et al. Moving torrefaction towards market introduction-Technical improvements and economic-environmental assessment along the overall torrefaction supply chain through the SECTOR project. Biomass Bioenergy 2016, 89, 184-200. [CrossRef]

209. McNamee, P.; Adams, P.W.R.; McManus, M.C.; Dooley, B.; Darvell, L.I.; Williams, A.; Jones, J.M. An assessment of the torrefaction of North American pine and life cycle greenhouse gas emissions. Energy Convers. Manag. 2016, 113, 177-188. [CrossRef]

210. Li, L.; Sun, Z.; Yao, X.; Wang, D. Optimal production scheduling for energy efficiency improvement in biofuel feedstock preprocessing considering work-in-process particle separation. Energy 2016, 96, 474-481. [CrossRef]

211. Chai, L.; Saffron, C.M. Comparing pelletization and torrefaction depots: Optimization of depot capacity and biomass moisture to determine the minimum production cost. Appl. Energy 2016, 163, 387-395. [CrossRef]

212. Li, J.; Paul, M.C.; Younger, P.L.; Watson, I.; Hossain, M.; Welch, S. Prediction of high-temperature rapid combustion behaviour of woody biomass particles. Fuel 2016, 165, 205-214. [CrossRef]

213. Miedema, J.H.; Moll, H.C.; Benders, R.M.J. Environmental and energy performance of the biomass to synthetic natural gas supply chain. J. Sustain. Dev. Energy Water Environ. Syst. 2016, 4, 262-278. [CrossRef]

214. Artiukhina, E.; Grammelis, P. Modeling of biofuel pellets torrefaction in a realistic geometry. Therm. Sci. 2016, $20,1223-1231$. [CrossRef]

215. Xu, J.; Chang, S.; Yuan, Z.; Jiang, Y.; Liu, S.; Li, W.; Ma, L. Regionalized Techno-Economic Assessment and Policy Analysis for Biomass Molded Fuel in China. Energies 2015, 8, 13846-13863. [CrossRef]

216. Williams, O.; Eastwick, C.; Kingman, S.; Giddings, D.; Lormor, S.; Lester, E. Investigation into the applicability of Bond Work Index (BWI) and Hardgrove Grindability Index (HGI) tests for several biomasses compared to Colombian La Loma coal. Fuel 2015, 158, 379-387. [CrossRef]

217. Huéscar Medina, C.; Phylaktou, H.N.; Andrews, G.E.; Gibbs, B.M. Explosion characteristics of pulverised torrefied and raw Norway spruce (Picea abies) and Southern pine (Pinus palustris) in comparison to bituminous coal. Biomass Bioenergy 2015, 79, 116-127. [CrossRef]

218. Tumuluru, J.S. High moisture corn stover pelleting in a flat die pellet mill fitted with a $6 \mathrm{~mm}$ die: Physical properties and specific energy consumption. Energy Sci. Eng. 2015, 3, 327-341. [CrossRef]

219. Adams, P.W.R.; Shirley, J.E.J.; McManus, M.C. Comparative cradle-to-gate life cycle assessment of wood pellet production with torrefaction. Appl. Energy 2015, 138, 367-380. [CrossRef]

220. Chiaramonti, D.; Rizzo, A.M.; Prussi, M.; Tedeschi, S.; Zimbardi, F.; Braccio, G.; Viola, E.; Pardelli, P.T. 2nd generation lignocellulosic bioethanol: Is torrefaction a possible approach to biomass pretreatment? Biomass Convers. Biorefinery 2011, 1, 9-15. [CrossRef] 